\title{
Future Changes in Climate over the Arabian Peninsula based on CMIP6 Multimodel Simulations
}

\author{
Mansour Almazroui $^{1} \oplus \cdot$ M. Nazrul Islam ${ }^{1} \cdot$ Sajjad Saeed $^{1,2,3} \cdot$ Fahad Saeed $^{1,4} \cdot$ Muhammad Ismail $^{1}$
}

Received: 28 December 2019 / Accepted: 20 October 2020 / Published online: 11 November 2020

(c) The Author(s) 2020

\begin{abstract}
This paper presents the changes in projected temperature and precipitation over the Arabian Peninsula for the twenty-first century using the Coupled Model Intercomparison Project phase 6 (CMIP6) dataset. The changes are obtained by analyzing the multimodel ensemble from 31 CMIP6 models for the near (2030-2059) and far (2070-2099) future periods, with reference to the base period 1981-2010, under three future Shared Socioeconomic Pathways (SSPs). Observations show that the annual temperature is rising at the rate of $0.63{ }^{\circ} \mathrm{C}$ decade $^{-1}$ (significant at the $99 \%$ confidence level), while annual precipitation is decreasing at the rate of $6.3 \mathrm{~mm} \mathrm{decade}^{-1}$ (significant at the $90 \%$ confidence level), averaged over Saudi Arabia. For the near (far) future period, the $66 \%$ likely ranges of annual-averaged temperature is projected to increase by $1.2-1.9(1.2-2.1)^{\circ} \mathrm{C}$, 1.4-2.1 (2.3-3.4) ${ }^{\circ} \mathrm{C}$, and 1.8-2.7 (4.1-5.8) ${ }^{\circ} \mathrm{C}$ under SSP1-2.6, SSP2-4.5, and SSP5-8.5, respectively. Higher warming is projected in the summer than in the winter, while the Northern Arabian Peninsula (NAP) is projected to warm more than Southern Arabian Peninsula (SAP), by the end of the twenty-first century. For precipitation, a dipole-like pattern is found, with a robust increase in annual mean precipitation over the SAP, and a decrease over the NAP. The $66 \%$ likely ranges of annual-averaged precipitation over the whole Arabian Peninsula is projected to change by 5 to 28 ( -3 to 29$) \%, 5$ to 31 (4 to 49 ) $\%$, and 1 to 38 (12 to 107) \% under SSP1-2.6, SSP2-4.5, and SSP5-8.5, respectively, in the near (far) future. Overall, the full ranges in CMIP6 remain higher than the CMIP5 models, which points towards a higher climate sensitivity of some of the CMIP6 climate models to greenhouse gas (GHG) emissions as compared to the CMIP5. The CMIP6 dataset confirmed previous findings of changes in future climate over the Arabian Peninsula based on CMIP3 and CMIP5 datasets. The results presented in this study will be useful for impact studies, and ultimately in devising future policies for adaptation in the region.
\end{abstract}

Keywords Projection $\cdot$ Temperature $\cdot$ Precipitation $\cdot$ Arabian peninsula $\cdot$ CMIP6

\section{Introduction}

The climate of the Arabian Peninsula is semi-arid to arid, with high annual temperatures and low precipitation, making it one of the most climate-vulnerable regions in the Middle East, as well as in Southwest Asia. The northern part of the

Mansour Almazroui

mansour@kau.edu.sa

1 Center of Excellence for Climate Change Research/ Department of Meteorology, King Abdulaziz University, PO Box 80208, Jeddah 21589, Saudi Arabia

2 The Abdus Salam International Center for Theoretical Physics, Trieste, Italy

3 Department of Earth and Environmental Sciences, University of Leuven (KU Leuven), Leuven, Belgium

4 Climate Analytics, Berlin, Germany
Arabian Peninsula is colder than the southern part. In different seasons, observed temperature ranges from 8.57 to $28.32{ }^{\circ} \mathrm{C}$ over the northern Peninsula, whereas temperature ranges from 26.68 to $33.97{ }^{\circ} \mathrm{C}$ in the southern Peninsula (Almzroui et al. 2013). During summertime, the maximum temperature may exceed $50{ }^{\circ} \mathrm{C}$ at some locations over the region (Almazroui et al. 2012; Islam et al. 2015; Pal et al. 2016). The wet season over Arabian Peninsula extends from October to May (Almazroui 2020a), while the dry season lasts from June through September. Over Saudi Arabia (about $80 \%$ coverage of the Peninsula area), the annual mean temperature varies from $18.96^{\circ} \mathrm{C}$ (in the northwest region) to $31.42{ }^{\circ} \mathrm{C}$ (in the western region), and the annual mean precipitation varies from $25 \mathrm{~mm}$ (in the northwest region) to $230 \mathrm{~mm}$ (in the southwest region) (Almazroui et al. 2012; Almazroui 2012). The wet season precipitation varies from $75 \mathrm{~mm}$ (in May) to $200 \mathrm{~mm}$ (in April) while the dry season 
precipitation ranges from $20 \mathrm{~mm}$ (in June) to $65 \mathrm{~mm}$ (in Aug) (Almazroui et al. 2017a).

Surface air temperature is a key component of climate variability and one of the major indicators of climate change on both regional and global scales (Kothawale et al. 2010). The global mean temperature increased by $\sim 0.6{ }^{\circ} \mathrm{C}$ during the period 1861-2000 (Folland et al. 2001), whereas global warming was $\sim 0.85{ }^{\circ} \mathrm{C}$ during the period $1880-2012$ (IPCC 2013). In the Peninsula, many studies (e.g. Almazroui et al. 2014; Islam et al. 2015) revealed a warming trend in recent decades. For the long-term period 1960-2010, the mean temperature increased significantly by $0.10{ }^{\circ} \mathrm{C}$ decade $^{-1}$ over the Peninsula (Attada et al. 2018a), while for recent decades (1978-2009), the rate of increase over Saudi Arabia $\left(0.60{ }^{\circ} \mathrm{C} \mathrm{decade}{ }^{-1}\right)$ has been even larger (Almazroui et al. 2012). Almazroui et al. (2012) found that the rainfall increase during the period 1979-1993 was insignificant, while the decrease over the period 1994-2009 was indeed significant. The rate of decrease was $35.1 \mathrm{~mm}$ decade $^{-1}$ for the wet season and $5.5 \mathrm{~mm}$ decade ${ }^{-1}$ for the dry season. Consistent with these results, AlSarmi and Washington (2013) showed that precipitation decreased over the Peninsula, and showed an insignificant trend for the time period 1986-2008. Hasanean and Almazroui (2015) also reported a downward trend in rainfall over the Arabian Peninsula for the period 1978-2009. Annual precipitation decreased significantly over northern regions of the Peninsula at a rate of $0.66 \%$ decade $^{-1}$, while an increasing trend $\left(1.67 \%\right.$ decade $\left.^{-1}\right)$ occurred over the southern Peninsula. However, precipitation increased at a rate of $0.86 \%$ decade $^{-1}$ over the whole Arabian Peninsula (Almazroui et al. 2017b).

The temperature and precipitation climatology, along with their trends mentioned above, were analyzed using observed climate data. Future climate projections over the Arabian Peninsula are studied using ensembles of global climate models, and also by downscaling them using regional climate models (e.g. Barfus and Bernhofer 2014; Pal et al. 2016; Almazroui et al. 2013b, 2016, 2017a, b, c; Syed et al. 2019). Using CMIP3 data, Almazroui et al. (2017c) showed that the annual mean temperature could increase by $2.32 \pm 2.45,3.49 \pm 2.49$, and $3.82 \pm 1.47^{\circ} \mathrm{C}$, compared to the present climate, under the $\mathrm{B} 1, \mathrm{~A} 1 \mathrm{~B}$, and $\mathrm{A} 2$ scenarios, respectively, by the end of the twenty-first century. Under the same scenarios, annual precipitation is projected to increase by $5.16 \pm 30,10.48 \pm 34$, and $15.29 \pm 43 \%$, relative to the present climate. Using CMIP5 data, Almazroui et al. (2017a) showed that at the end of the twenty-first century, the temperature could increase by $2.51 \pm 0.72$, or $4.87 \pm 0.86{ }^{\circ} \mathrm{C}$ relative to the present-day climate, under the RCP4.5 and RCP8.5 scenarios, respectively. For precipitation, the corresponding projections under these scenarios found an increase in annual precipitation by $8.27 \pm 20$ and $27.34 \pm 50 \%$, respectively. Using both CMIP3 and CMIP5 datasets, they noted that temperature would continue to increase throughout the twenty-first century over the Peninsula, that rainfall will increase over the southern regions of the Peninsula while it will decrease over the northwest region. Similar results were found by Bucchignani et al. (2018) using a regional climate model (COSMO-CLM) simulations. Moreover, climate change increases the risk of extreme events, particularly those related to temperature, which may be responsible for heat/cold waves and frequent drought occurrence over any region (Kotwicki and $\mathrm{Al}$ Sulaimani, 2009). Recently, Almazroui (2019) found that over the Peninsula, an increase in the frequency of hot days, and reduction in the occurrence of cold nights, will be more likely in the far future (2071-2100) under RCP8.5 as compared to the near future (2021-2050). Extreme precipitation events will intensify more over the Peninsula, particularly over central and southern regions, in the future climate under RCP8.5 (Almazroui and Saeed 2020).

The Intergovernmental Panel on Climate Change (IPCC) Fifth Assessment Report (AR5) was mainly based on the CMIP5 GCM simulations. Recently, the simulations of some of the climate models for the sixth phase of the Coupled Model Intercomparison Project (CMIP6) have been completed and made available for analysis (Eyring et al. 2016; Haarsma et al. 2016; O'Neill et al. 2016). The CMIP6 dataset is based on a new generation of climate models, a new

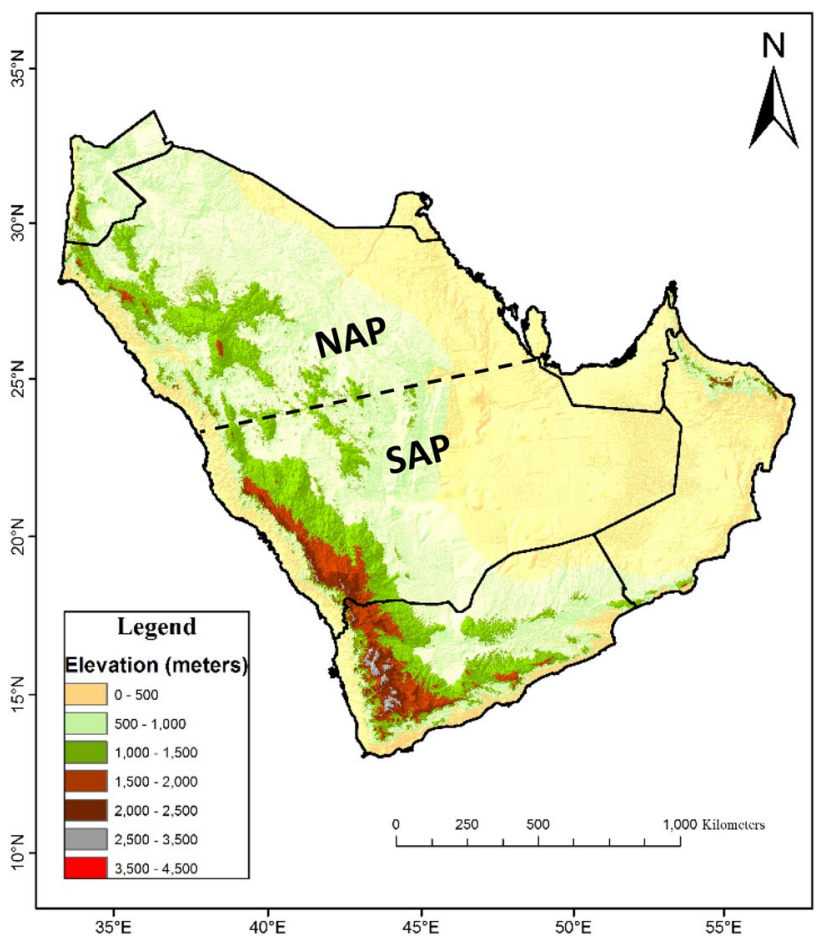

Fig. 1 Regional map showing elevation (in meters) over the Arabian Peninsula. The horizontal dashed line divides the analysis domain into northern Arabian Peninsula (NAP) and the southern Arabian Peninsula (SAP) used for area averages in this study 
Table 1 List of CMIP6 models used in this study along with horizontal resolution and country of origin

\begin{tabular}{|c|c|c|c|c|c|}
\hline No & CMIP6 model name & Country & $\begin{array}{l}\text { Horizontal resolution (lon. } \\
\text { by lat. in degree) }\end{array}$ & Variant label & Key references \\
\hline 1 & ACCESS-CM2 & Australia & $1.9^{\circ} \times 1.3^{\circ}$ & r1i1p1f1 & Bi et al. (2012) \\
\hline 2 & ACCESS-ESM1-5 & Australia & $1.9^{\circ} \times 1.2^{\circ}$ & rli1p1f1 & Law et al. (2017) \\
\hline 3 & AWI-CM-1-1-MR & Germany & $0.9^{\circ} \times 0.9^{\circ}$ & r1i1p1f1 & Semmler et al. (2020, in review) \\
\hline 4 & BCC-CSM2-MR & China & $1.1^{\circ} \times 1.1^{\circ}$ & r1i1p1f1 & Wu et al. (2019) \\
\hline 5 & CAMS-CSM1-0 & China & $1.1^{\circ} \times 1.1^{\circ}$ & r1i1p1f1 & Rong et al (2019) \\
\hline 6 & CanESM5 & Canada & $2.8^{\circ} \times 2.8^{\circ}$ & rli1p1f1 & Swart et al (2019) \\
\hline 7 & CESM2 & USA & $1.3^{\circ} \times 0.9^{\circ}$ & rli1p1f1 & Lauritzen et al (2018) \\
\hline 8 & CESM2-WACCM & USA & $1.3^{\circ} \times 0.9^{\circ}$ & rli1p1f1 & Liu et al (2019) \\
\hline 8 & CIESM & China & $0.9^{\circ} \times 1.3^{\circ}$ & r1i1p1f1 & Lin et al. (2020) \\
\hline 10 & CNRM-CM6-1 & France & $1.4^{\circ} \times 1.4^{\circ}$ & rli1p1f2 & Voldoire et al (2019) \\
\hline 11 & CNRM-CM6-1-HR & France & $0.5^{\circ} \times 0.5^{\circ}$ & r1i1p1f2 & Voldoire et al (2019) \\
\hline 12 & CNRM-ESM2-1 & France & $1.4^{\circ} \times 1.4^{\circ}$ & r1ilp1f2 & Séférian et al (2019) \\
\hline 13 & EC-Earth3 & Europe & $0.7^{\circ} \times 0.7^{\circ}$ & r1i1p1f1 & Massonnet et al. (2020) \\
\hline 14 & EC-Earth3-Veg & Europe & $0.7^{\circ} \times 0.7^{\circ}$ & rli1p1f1 & Not available \\
\hline 15 & FGOALS-f3-L & China & $1.3^{\circ} \times 1^{\circ}$ & rli1p1f1 & He et al (2019) \\
\hline 16 & FGOALS-g3 & China & $2^{\circ} \times 2.3^{\circ}$ & rli1p1f1 & Not available \\
\hline 17 & FIO-ESM-2-0 & China & $1.3^{\circ} \times 0.9^{\circ}$ & r1i1p1f1 & Song et al. (2020) \\
\hline 18 & GFDL-ESM4 & USA & $1.3^{\circ} \times 1^{\circ}$ & rli1p1f1 & Held et al (2019) \\
\hline 19 & INM-CM4-8 & Russia & $2^{\circ} \times 1.5^{\circ}$ & r1i1p1f1 & Volodin et al. (2018) \\
\hline 20 & INM-CM5-0 & Russia & $2^{\circ} \times 1.5^{\circ}$ & r1i1p1f1 & Volodin et al. (2018) \\
\hline 21 & IPSL-CM6A-LR & France & $2.5^{\circ} \times 1.3^{\circ}$ & r1ilp1f1 & Not available \\
\hline 22 & KACE-1-0-G & South Korea & $1.3^{\circ} \times 0.9^{\circ}$ & rlilp1f1 & Not available \\
\hline 23 & MIROC6 & Japan & $1.4^{\circ} \times 1.4^{\circ}$ & r1ilp1f1 & Tatebe et al (2019) \\
\hline 24 & MIROC-ES2L & Japan & $2.8^{\circ} \times 2.8^{\circ}$ & r1ilp1f2 & Hajima et al (2019) \\
\hline 25 & MPI-ESM1-2-HR & Germany & $0.9^{\circ} \times 0.9^{\circ}$ & r1i1p1f1 & Gutjahr et al (2019) \\
\hline 26 & MPI-ESM1-2-LR & Germany & $1.9^{\circ} \times 1.9^{\circ}$ & r1i1p1f1 & Mauritsen et al. (2019) \\
\hline 27 & MRI-ESM2-0 & Japan & $1.1^{\circ} \times 1.1^{\circ}$ & r1i1p1f1 & Yukimoto et al (2019) \\
\hline 28 & NESM3 & China & $1.9^{\circ} \times 1.9^{\circ}$ & rli1p1f1 & Cao et al (2018) \\
\hline 29 & NorESM2-LM & Norway & $2.5^{\circ} \times 1.9^{\circ}$ & r1ilp1f1 & Seland et al. (2020, in review) \\
\hline 30 & NorESM2-MM & Norway & $0.9^{\circ} \times 1.3^{\circ}$ & rli1p1f1 & Seland et al. (2020, in review) \\
\hline 31 & UKESM1-0-LL & UK & $1.9^{\circ} \times 1.3^{\circ}$ & r1ilp1f2 & Sellar et al (2019) \\
\hline
\end{tabular}

start year for the future scenarios (2006 in CMIP5; 2015 in CMIP6), and employed a new set of concentrations, emissions, and land-use scenarios (Riahi et al. 2017; O'Neill et al. 2016). This work is the first attempt to examine the projected changes in temperature and precipitation over the Arabian Peninsula using the CMIP6 dataset. The present study further investigates the extent to which the CMIP6 model-simulated climate response to anthropogenic forcing over the Arabian Peninsula differs from those of the CMIP3 and CMIP5 datasets. To the best of our knowledge, no other study has examined future climate change over the Arabian Peninsula using the CMIP6 dataset. Such an analysis of CMIP6 model output over the Arabian Peninsula is important for determining how both CMIP5 and CMIP6 results could be used together in future impact and adaptation studies. The present study aims to fill this gap by analyzing the dataset from 31 CMIP6 models over the Arabian Peninsula.

\section{Data and Methodology}

The surface observations for temperature and precipitation for the period 1978-2019 are obtained from 25 station locations across Saudi Arabia collected by the Saudi General Authority of Meteorology and Environmental Protection (GAMEP). The observational temperature and precipitation gridded data used are from the Climatic Research Unit (CRU, Harris and Jones 2015) along with the Global Precipitation Climatology Center (GPCC) version 7 (Schneider et al. 2016) for precipitation, and the University of Delaware 

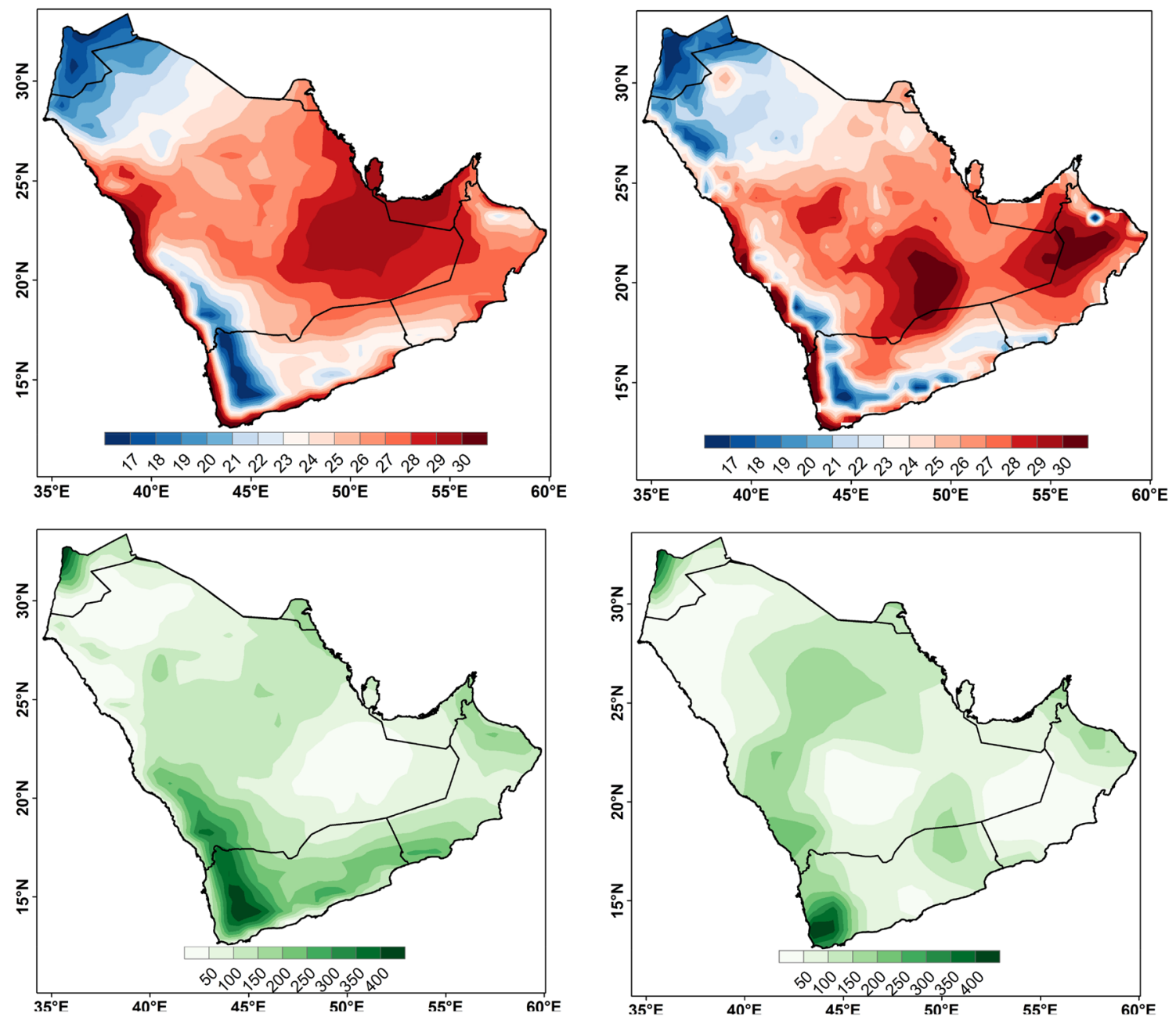

Fig. 2 Observed spatial distribution of temperature (upper panels) and precipitation (lower panels) averaged over the period 1981-2010. The temperature is obtained from gridded CRU (top left) and UoD

(UoD) version 5.01 dataset (Willmott and Matsuura 2001) for temperature. The gridded data are used over the Arabian Peninsula, where the elevation varies from 1 to above $2500 \mathrm{~m}$ (Fig. 1). The Peninsula is almost flat to the east of the eastern border of Jordan with Iraq to the eastern border of Yemen with Oman, where all Gulf countries are located, along with the eastern part of Saudi Arabia. The Hijaz Mountains range is in the northwest of Saudi Arabia, whereas the Asir Mountains range from western Saudi Arabia and continue southeastward into Yemen. The Asir Mountains receive the most annual precipitation of anywhere in the Peninsula (Almazroui et al. 2012).

The climate model data is obtained from the CMIP6 database (https://esgf-node.llnl.gov/search/cmip6). The 31 CMIP6 models analyzed in this study are listed in Table 1. Since each of the CMIP6 constituent models has different horizontal resolutions, all CMIP6 data sets are regridded from their original spatial resolutions to a

(top right) whereas precipitation is obtained from CRU (bottom left) and GPCC (bottom right) data. The units of temperature is ${ }^{\circ} \mathrm{C}$, and precipitation is in $\mathrm{mm}_{\text {year }}{ }^{-1}$

common grid with $1 \times 1$ degree resolution. The temperature data are regridded using a standard bilinear interpolation technique, while the precipitation data are regridded using a first-order conservative method. For the analysis of temperature and precipitation data, annual averages are taken over the 30-year time slots for the base period (1981-2010), near future (2030-2059), and far future (2070-2099). Moreover, for seasonal analysis, the summer (JJA) and winter (DJF) seasons are considered for temperature while the wet season (Oct-May) is considered for precipitation. The definition of the wet season over the Arabian Peninsula is adopted from Almazroui (2011, 2020a). In addition to seasonal analysis, regional analysis is performed separately on the northern Arabian Peninsula and the southern Arabian Peninsula due to their differing weather characteristics (Almazroui et al. 2013a, b, 2016, 2017b). 
Fig. 3 Observed temperature (a) and precipitation (b) anomalies for the period 1978-2019 with respect to the climatology 1981-2010. Both the temperature and precipitation anomalies are obtained by taking averages from 25 stations observed data (Table 2)
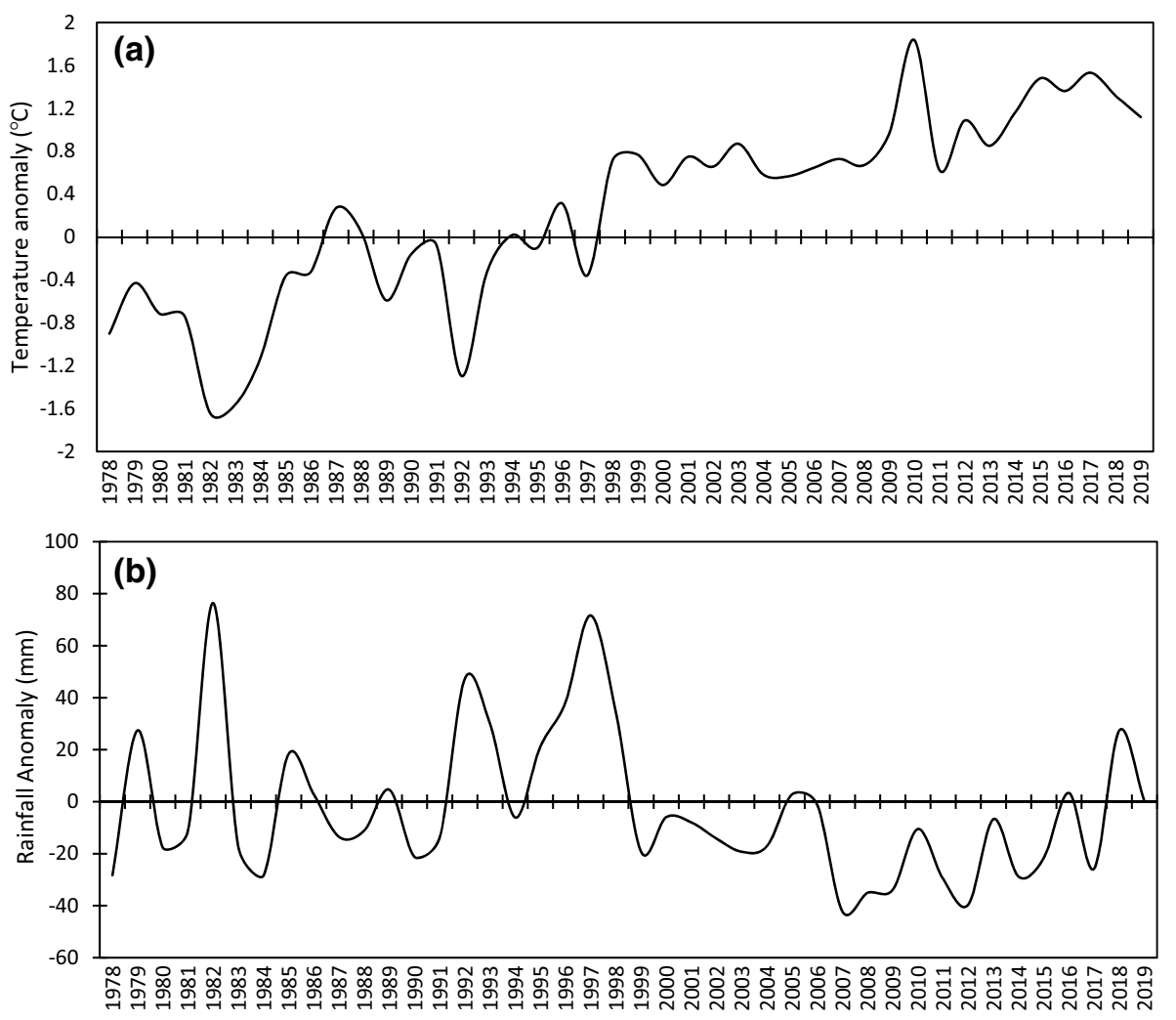

The ensemble from the 31 available CMIP6 models for the present and future climates, along with the range of signals, are considered for temperature and precipitation analyses under the three new future pathways of societal development called Shared Socioeconomic Pathways (SSPs), which are: a low-forcing scenario SSP1-2.6, a medium-forcing scenario SSP2-4.5, and a high-forcing scenario SSP5-8.5. Note that SSPs are based on five narratives that describe alternative socio-economic developments (Riahi et al. 2017): sustainable development (SSP1), middle-of-the-road development (SSP2), regional rivalry (SSP3), inequality (SSP4), and fossil-fuels development (SSP5). Detailed descriptions of these SSPs are available in O'Neill et al. (2016). The SSP1-2.6, SSP2-4.5 and SSP5-8.5 forcing scenarios are considered for, respectively, low, medium and high emission scenarios, similar to the RCP2.6, RCP4.5, and RCP8.5 scenarios in CMIP5 models (Riahi et al. 2017). For the assessment of uncertainty associated with the future evaluation of temperature and precipitation under the SSPs, the likely range (66\% i.e. 17-83 percentile around the median) and the full range (results from all models) are used along with median values. Furthermore, the robustness of the projected signal is measured based on the agreement of different model projections on the direction of changes (Solomon et al. 2007). According to Haensler et al. (2013), the changes, whether an increase or a decrease, in the projected signal, will be considered robust if at least $66 \%$ of the models agree on the direction of change. In addition, the significance of a change in the projected signal is measured by employing a two-tailed Student $t$ test based on equal and unequal variances between future and historical data for each grid box. Equal and unequal variance is determined for each grid box using an $F$ test. Analyses are performed over the entire Arabian Peninsula (AP), NAP and SAP. Temperature and precipitation trends are calculated using regression analysis, while the statistical significance of trends is assessed by an $F$ test (Almazroui et al. 2013a).

\section{Results and Discussion}

The distribution of observed temperature and precipitation climatology for the period 1981 to 2010 is shown in Fig. 2. The time period 1981-2010 is selected for the climatology because it is used as the reference (base) period to obtain the changes in simulated climate from the CMIP6 models. The observed data shows that the temperature in the northwest and southwest mountain areas is lower than in the central to eastern regions, as seen in both the CRU and UoD datasets. The annual mean temperature is below $20^{\circ} \mathrm{C}$ in the northwestern and southwestern regions, while it exceeds $30^{\circ} \mathrm{C}$ in the central to eastern regions. The CRU data shows large precipitation in the southwest Peninsula, which can exceed 
Table 2 Surface observational mean annual temperature (in ${ }^{\circ} \mathrm{C}$ ) and precipitation (in $\mathrm{mm}$ ) along with their trends $\left(\right.$ decade $^{-1}$ ) at 25 stations across Saudi Arabia for the period 1978-2019

\begin{tabular}{|c|c|c|c|c|c|c|}
\hline & \multirow[t]{2}{*}{ Station name } & \multirow[t]{2}{*}{ WMO code } & \multicolumn{2}{|l|}{ Temperature $\left({ }^{\circ} \mathrm{C}\right)$} & \multicolumn{2}{|c|}{ Precipitation (mm) } \\
\hline & & & Annual Average & Trend & Annual Average & Trend \\
\hline \multirow[t]{15}{*}{ Northern Arabian Peninsula } & Tabuk & 40,375 & 22.37 & $0.45^{\mathrm{a}}$ & 31.4 & -2 \\
\hline & Turaif & 40,356 & 19.10 & $0.38^{\mathrm{a}}$ & 84.9 & $-14^{\mathrm{a}}$ \\
\hline & Guriat* & 40,360 & 20.27 & $0.42^{\mathrm{a}}$ & 48.7 & 0 \\
\hline & Rafha & 40,362 & 23.57 & $0.59^{\mathrm{a}}$ & 80.6 & -7 \\
\hline & Arar & 40,357 & 22.46 & $0.68^{\mathrm{a}}$ & 59.7 & -3 \\
\hline & Al-Jouf & 40,361 & 22.26 & $0.81^{\mathrm{a}}$ & 56.1 & 5 \\
\hline & Hail & 40,394 & 22.15 & $0.63^{\mathrm{a}}$ & 97.4 & $-30^{\mathrm{a}}$ \\
\hline & Gassim & 40,405 & 25.18 & $0.73^{\mathrm{a}}$ & 131.3 & $-19^{\mathrm{b}}$ \\
\hline & Riyadh* & 40,437 & 25.71 & $0.64^{\mathrm{a}}$ & 105.5 & -14 \\
\hline & Al-Qaisumah & 40,373 & 25.58 & $0.55^{\mathrm{a}}$ & 120.7 & -11 \\
\hline & Dammam & 40,417 & 27.36 & $0.40^{\mathrm{a}}$ & 87.4 & 16 \\
\hline & $\mathrm{Al}-\mathrm{Ahsa}^{*}$ & 40,420 & 27.51 & $0.68^{\mathrm{a}}$ & 86.5 & -3 \\
\hline & Al-Wejh & 40,400 & 25.25 & $0.49^{\mathrm{a}}$ & 31.1 & 6 \\
\hline & Madinah & 40,430 & 28.37 & $0.47^{\mathrm{a}}$ & 61.0 & -5 \\
\hline & Yenbo & 40,439 & 28.04 & $0.58^{\mathrm{a}}$ & 33.0 & 4 \\
\hline \multirow[t]{11}{*}{ Southern Arabian Peninsula } & Jeddah & 41,024 & 28.90 & $0.41^{\mathrm{a}}$ & 51.2 & 1 \\
\hline & Taif & 41,036 & 23.20 & $0.41^{\mathrm{a}}$ & 162.6 & -5 \\
\hline & Makkah* & 41,030 & 31.68 & $0.76^{\mathrm{a}}$ & 98.1 & -13 \\
\hline & $\mathrm{Al}-\mathrm{Baha}{ }^{*}$ & 41,055 & 23.27 & $0.45^{\mathrm{a}}$ & 131.5 & -19 \\
\hline & Gizan & 41,140 & 30.79 & $0.24^{\mathrm{a}}$ & 127.8 & 10 \\
\hline & Khamis Mushait & 41,114 & 20.11 & $0.67^{\mathrm{a}}$ & 184.6 & -12 \\
\hline & Abha & 41,112 & 19.22 & $0.62^{\mathrm{a}}$ & 221.2 & $-25^{\mathrm{b}}$ \\
\hline & Bisha & 41,084 & 25.35 & $0.51^{\mathrm{a}}$ & 86.4 & -8 \\
\hline & Najran & 41,128 & 25.21 & $0.54^{\mathrm{a}}$ & 60.3 & 9 \\
\hline & Sharorah* & 41,136 & 27.90 & $0.38^{\mathrm{a}}$ & 57.8 & -4 \\
\hline & Country & & 24.64 & $0.63^{a}$ & 92.9 & $-6.3^{b}$ \\
\hline
\end{tabular}

The stations with * indicate data from 1985

The superscript $a$ and $b$ represent statistical significance level 99\% and 90\% respectively

$400 \mathrm{~mm}$ annually. The precipitation is low (below $60 \mathrm{~mm}$ ) in the northwest part, and over the Rub Al-Khali desert areas. The GPCC data shows a similar distribution of precipitation to the CRU data. There is little variation between the datasets, and overall distributions of temperature and precipitation remain almost the same. The next sections describe the change in temperature over the Arabian Peninsula for the near and far future periods.

The historical trends of temperature and precipitation over Saudi Arabia (which represents $80 \%$ of the Peninsula) using the quality controlled and updated data for the period 1978-2019 indicate that the region continues to warm and to dry (Fig. 3). The temperature was slightly below normal $\left(24.39{ }^{\circ} \mathrm{C}\right)$ before 1997 and above normal afterward. The sharp peak in 2010 indicates the warmest year in the historical record. Regression anaylysis shows that the temperature increased at a rate of $0.63{ }^{\circ} \mathrm{C}$ decade $^{-1}$ for the period 1978-2019, which is significant at the $99 \%$ confidence level. Almazroui (2020a) also found a similar increasing rate in observed annual mean temperatures over the Arabian Peninsula. Annual precipitation is highly variable, however, it tends to be slightly below normal $(96.92 \mathrm{~mm})$ after 1998. Precipitation is decreasing at a rate of $6.3 \mathrm{~mm}$ decade $^{-1}$, which is statistically insignificant. Almazroui (2020b) also found a decreasing trend in observed annual precipitation over Saudi Arabia. Details of the temperature

Fig. 4 Spatial distribution of absolute change in annual mean temperature under three scenarios (SSP1-2.6, SSP2-4.5, and SSP5-8.5) over the Arabian Peninsula for the two time periods (2030-2059 and 2070-2099) as compared to the reference period (1981-2010). The backslash and forward slash represent the grid boxes showing significant and robust change, respectively, while hatching represents the grid boxes having both significant and robust change. Significance is defined based on a two-tailed Student $t$ test, while robustness is defined when $66 \%$ of all models project a climate change signal in the same direction 

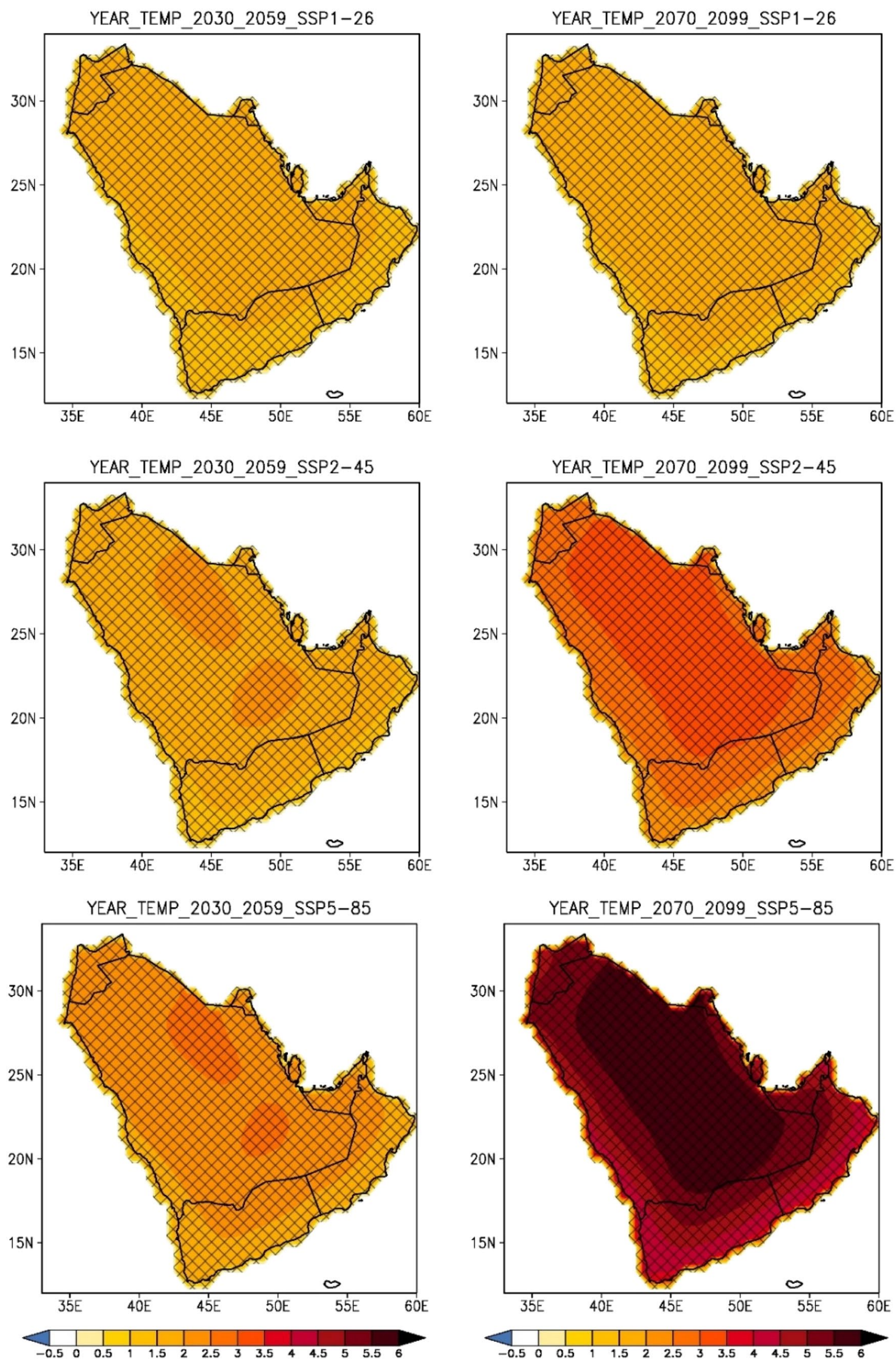

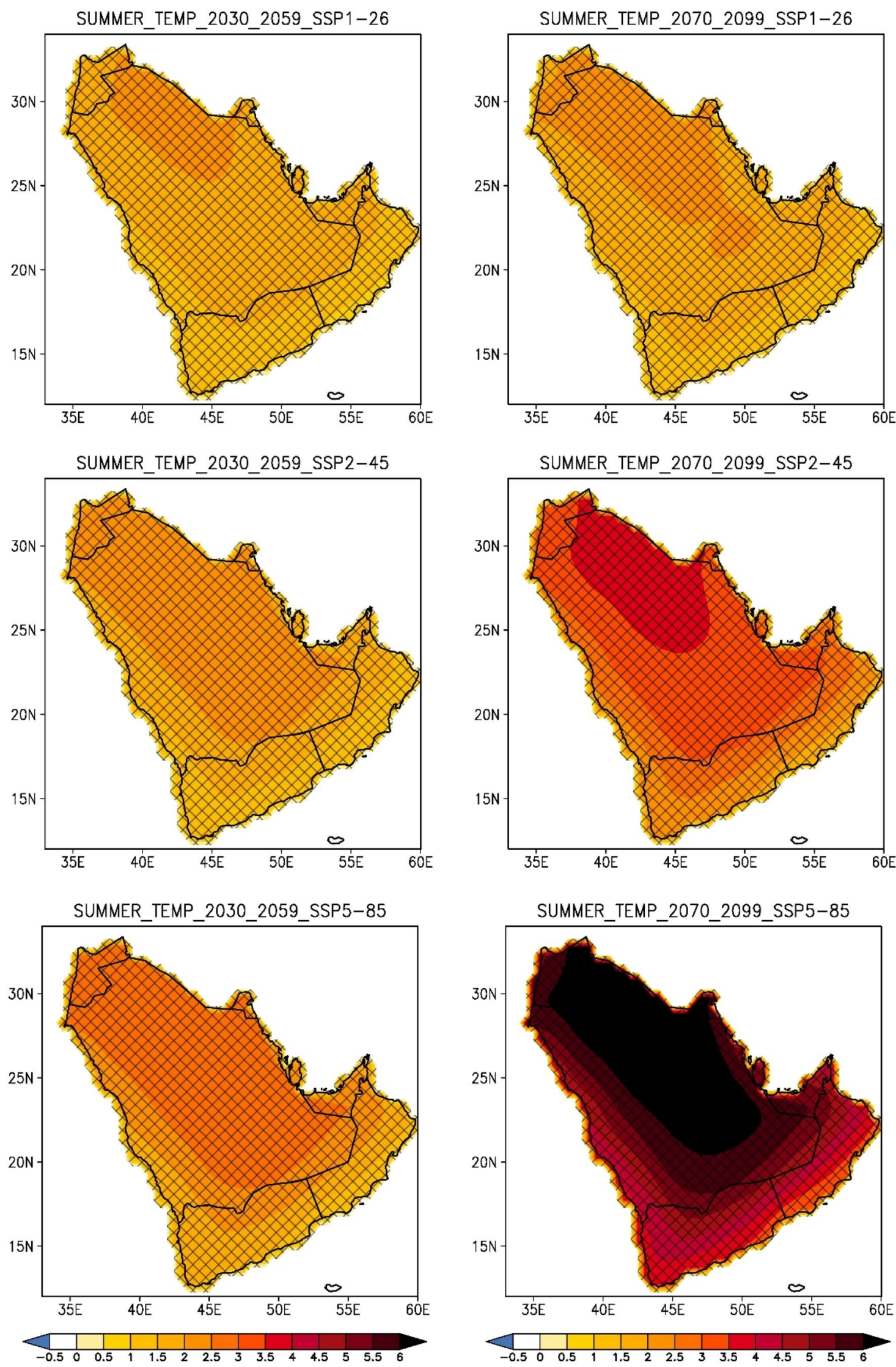

Fig. 5 Same as Fig. 4 but for summer season mean temperature 

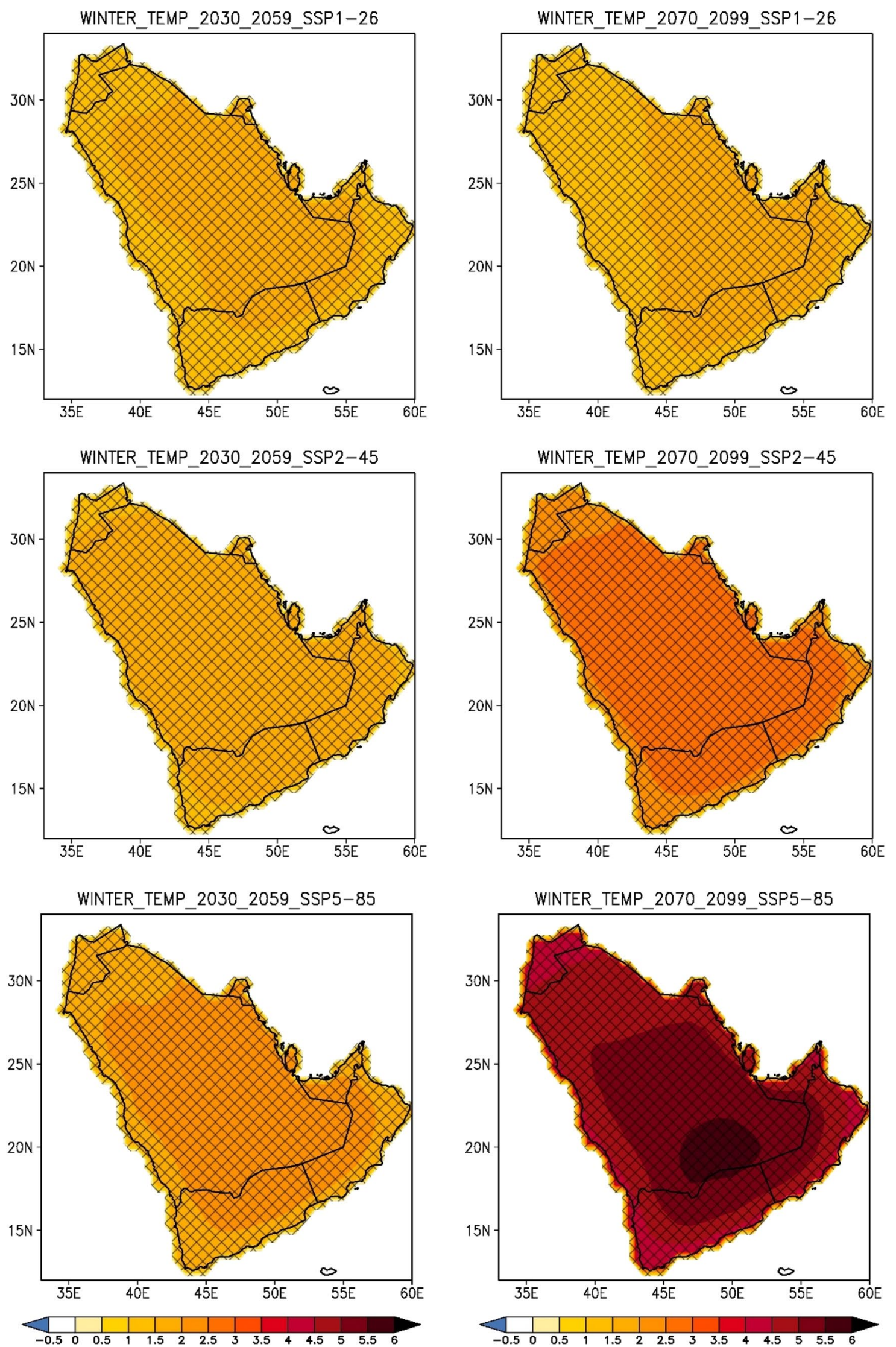

Fig. 6 Same as Fig. 4 but for winter season mean temperature 

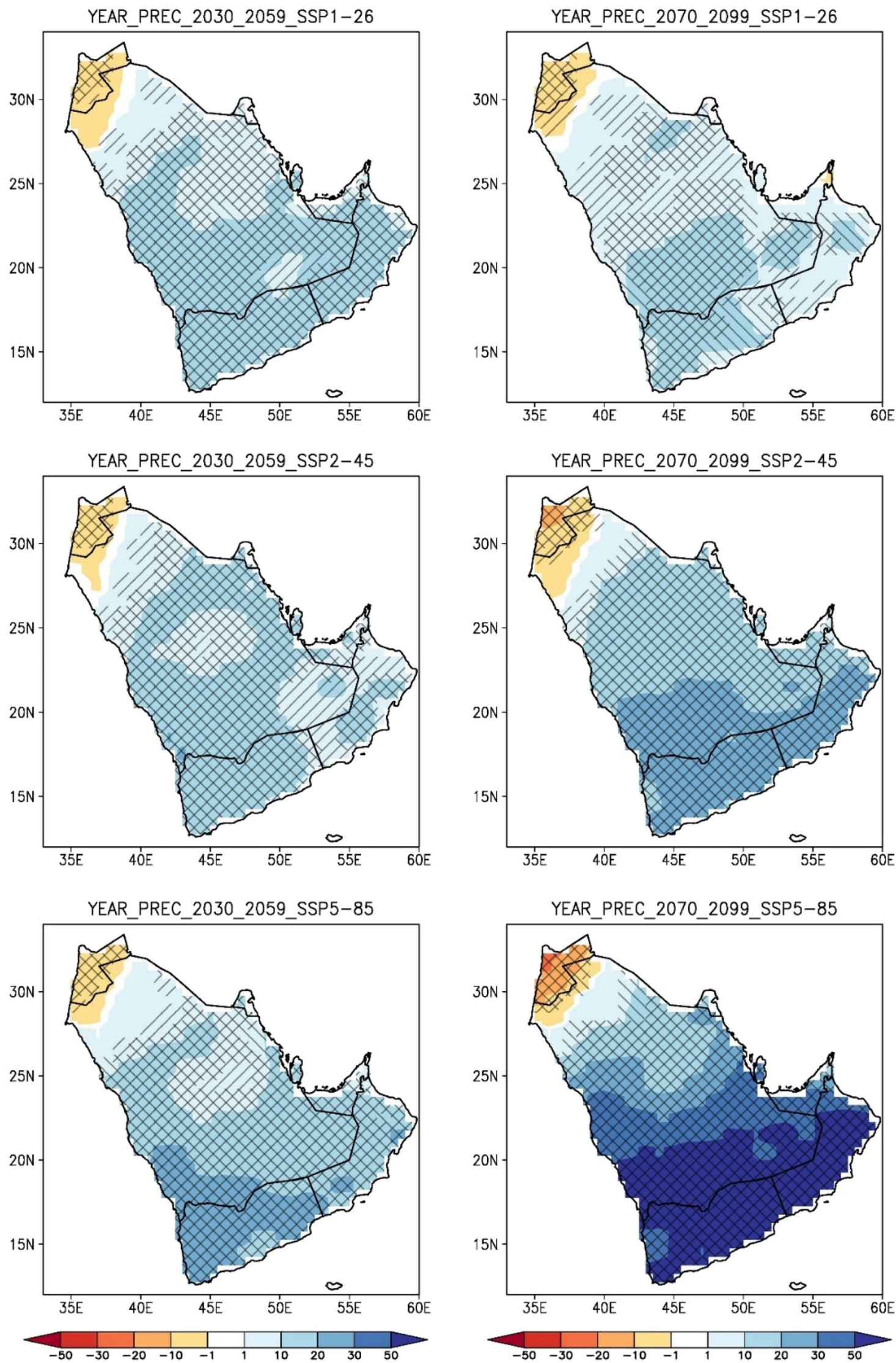
4Fig. 7 Spatial distribution of relative change in annual precipitation for three scenarios (SSP1-2.6, SSP2-4.5, and SSP5-8.5) over the Arabian Peninsula for the two time periods (2030-2059 and 2070-2099) as compared to the reference period (1981-2010). The backslash and forward slash represent the grid boxes showing significant and robust change, respectively, while hatching represents the grid boxes having both significant and robust change. Significance is defined based on a two-tailed Student $t$ test, while robustness is defined when $66 \%$ of all models project a climate change signal in the same direction

and precipitation trends at all 25 station locations across Saudi Arabia are provided in Table 2. Overall, a larger rate of increase in temperature is observed in the northern Peninsula relative to the southern Peninsula, which ranges from $0.24{ }^{\circ} \mathrm{C} \mathrm{decade}^{-1}$ (at Gizan) to $0.81{ }^{\circ} \mathrm{C} \mathrm{decade}^{-1}$ (et al.-Jouf), and are all significant at the $99 \%$ confidence level. Precipitation trends range from $-30 \mathrm{~mm}$ decade $^{-1}$ (at Hail) to $16 \mathrm{~mm}$ decade $^{-1}$ (at Dammam). Except for four stations, precipitation trends are statistically insignificant. The increasing temperature and decreasing precipitation trends are in line with previous findings obtained for a relatively shorter period (1978-2009) by Almazroui et al. (2012), who reported temperature increase at a rate of $0.60{ }^{\circ} \mathrm{C} \mathrm{decade}{ }^{-1}$ and precipitation decrease at a rate of $6.20 \mathrm{~mm} \mathrm{decade}^{-1}$. Note that the non-parametric Mann-Kendall trend analysis for the same data period over Saudi Arabia show almost similar trends for temperature and precipitation, however, to compare results with available literature and IPCC repot, linear trends are considered in this analysis (Almazroui 2020b).

\subsection{Changes in temperature for the near and far futures}

The spatial distribution of changes in projected temperature for the near and far futures under all three future scenarios are shown in Figs. 4, 5, and 6. The robust changes in temperature at annual scale over most parts of the Arabian Peninsula are projected to be below $2.0^{\circ} \mathrm{C}$ in the near future under the low emission scenario SSP1-2.6 (top panels, Fig. 4). Very similar patterns of changes in annual temperature are obtained for the far future. Robust changes in temperature are also noted for the medium emission scenario SSP2-4.5, where most parts of the Peninsula will be $2.0{ }^{\circ} \mathrm{C}$ warmer than the present climate in the near future period, and 3.0 to $4.05{ }^{\circ} \mathrm{C}$ warmer in the far future (middle panels, Fig. 4). The high emission scenario SSP5-8.5 indicates a rise in temperature by $3.0{ }^{\circ} \mathrm{C}$ compared to the present climate over the entire Peninsula for the near future and more than $4.5^{\circ} \mathrm{C}$ over most of the Arabian Peninsula. Under the SSP5-8.5 scenario, some parts of the Peninsula in the north-central region may exceed $6^{\circ} \mathrm{C}$ in the far future (lower panels, Fig. 4). This rise of temperature is consistent with CMIP5 data analysis over South Asia under RCP8.5, which is in the range $3.2-5.1{ }^{\circ} \mathrm{C}$ for the period $2070-2099$ (Alamgir et al. 2019). Overall, the change in the future temperature over the northern Peninsula is bigger (exceeding $6.0^{\circ} \mathrm{C}$ ) than over the southern Peninsula, which is in line with the CMIP3 and CMIP5 projections, as shown in Almazroui et al. (2016, 2017b). Summer temperatures over the Arabian Peninsula show a robust increase with a similar pattern to that of annual temperature. However, the magnitude of the temperature increase is more than $4.5^{\circ} \mathrm{C}$ in the northern Peninsula under the medium emission scenario (Fig. 5). In this season, the area with a temperature increase above $6.0^{\circ} \mathrm{C}$ expands towards the south, east, and west. In the case of winter temperature, the increase is lower than the annual and summer seasons in the northern Peninsula under a low emission scenario for the far future (Fig. 6). The higher increase in temperature over the northern Peninsula compared to the southern Peninsula observed in the summer season is not observed in the winter season. This feature is in line with the results from CMIP3 and CMIP5, as reported in Almazroui et al. (2016, 2017b). Note that the summer temperature of the Peninsula is highly correlated with the quasi-stationary mid-latitude Eurasian Rossby wave train pattern and the Atlantic Ocean sea surface temperature (Attada et al. 2018b; Ehsan et al. 2020; Rashid et al. 2020).

\subsection{Changes in Precipitation for the Near and Far Futures}

The spatial distribution of changes in projected precipitation for the near and far futures under all three SSPs are shown in Figs. 7 and 8. The projected precipitation shows a robust increase in annual mean precipitation over most of the Peninsula by the end of the twenty-first century under the three future scenarios. A decreasing signal is found over Jordan and adjacent areas of Saudi Arabia which get further intensified under high emission scenario SSP5-8.5. Annual precipitation is projected to decrease in the northwest and increase in the southern region (Fig. 7). The maximum deficit will be about 30\%, and the surplus will exceed 50\% under SSP5-8.5 in the far future. It is important to mention that because of its hyper-arid climate, the amount of precipitation in the southeastern region is very small. Therefore, a small increase in absolute precipitation may result in a large increase in relative (percentage) terms (Almazroui et al. 2017a; Almazroui and Saeed 2020). Note that the large increase over southwest Saudi Arabia is significant because the annual rainfall is highest in this region. The projected precipitation shows a decrease in the northwest region, which is more pronounced in the far future compared to the near future period, especially for the SSP5-8.5 scenario. This is in agreement with previous findings over the Arabian Peninsula based on CMIP3 and CMIP5 datasets (Almazroui et al. 2017a, b). 

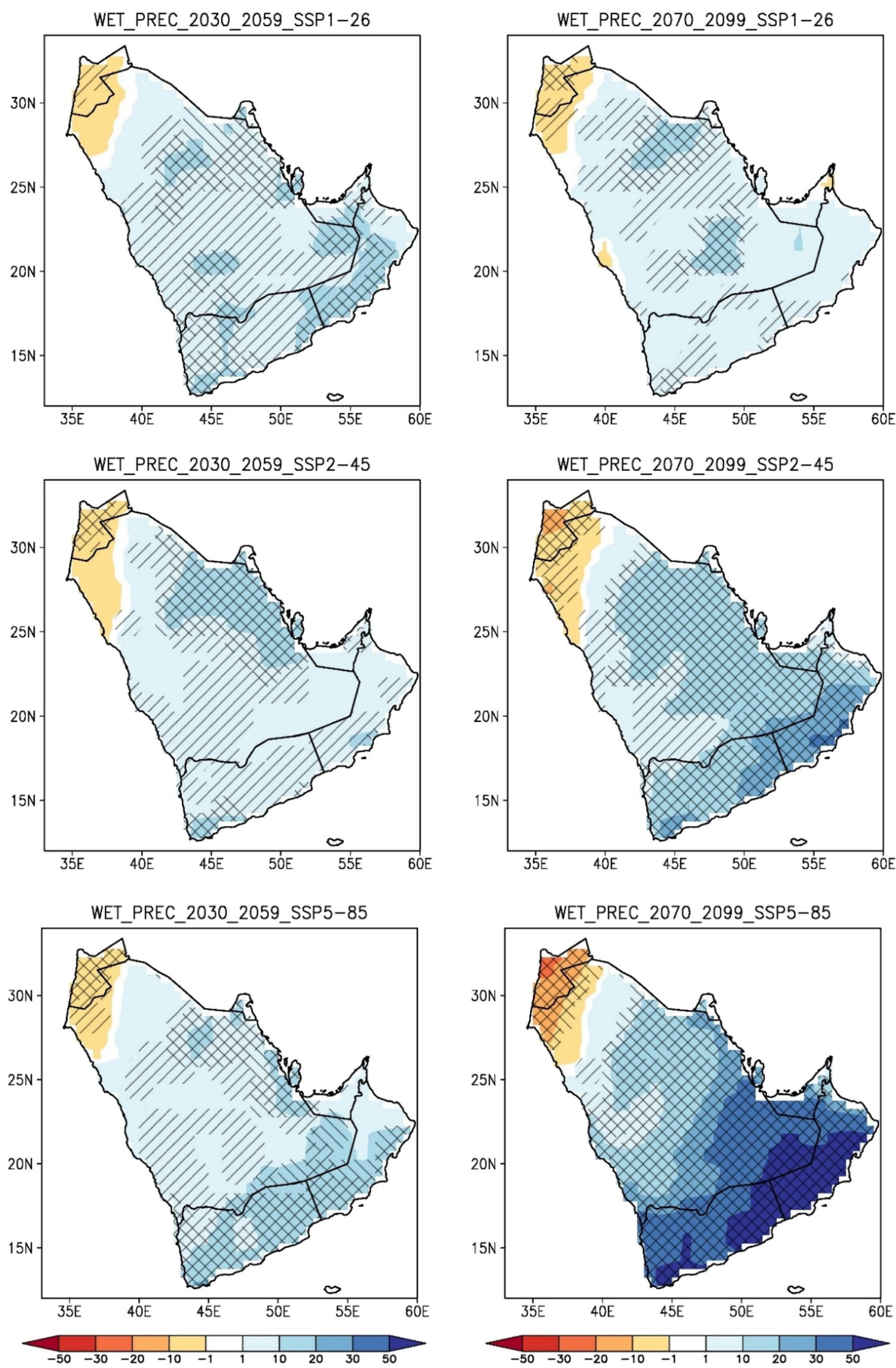

Fig. 8 Same as Fig. 7 but for wet season precipitation 

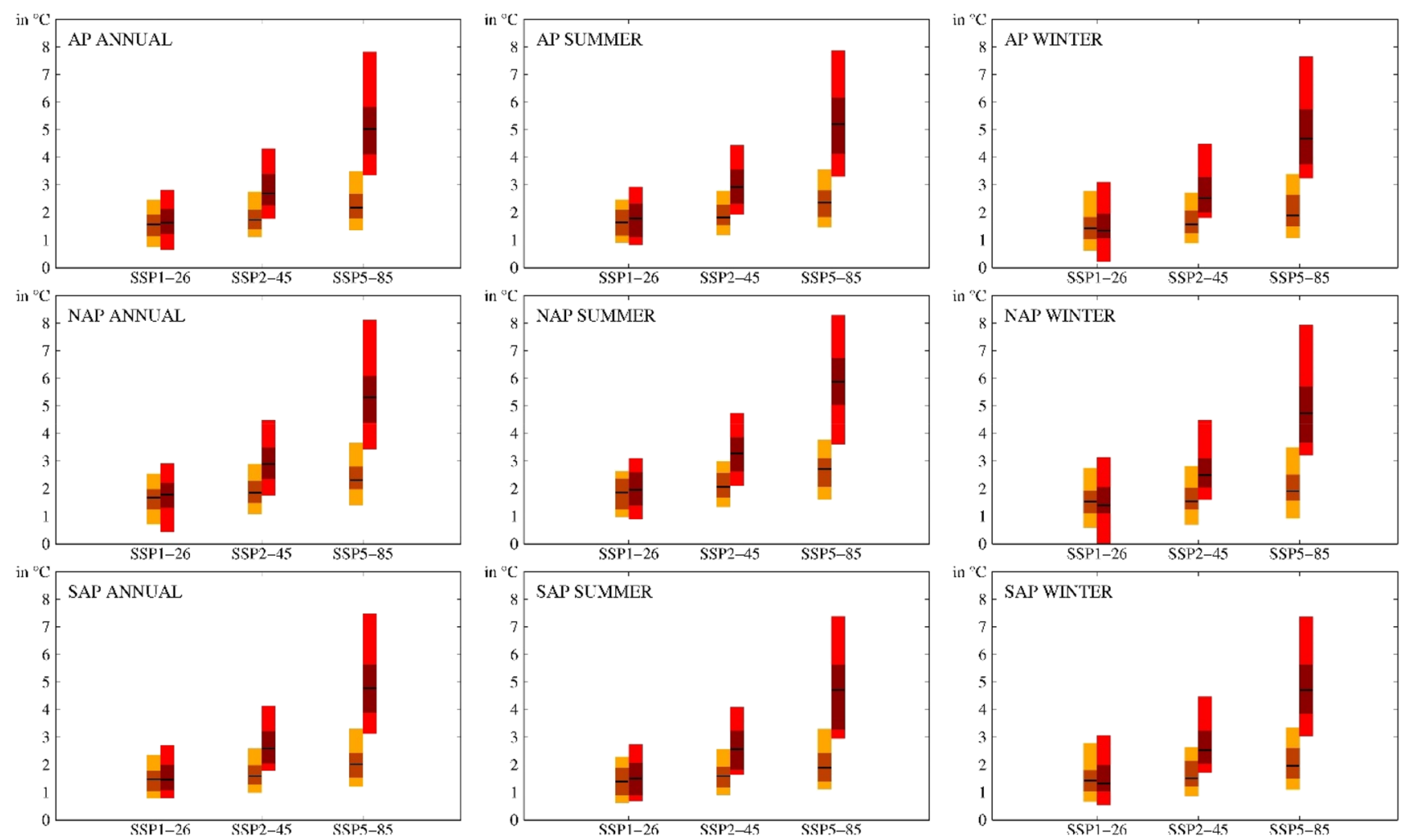

Fig. 9 Projected changes in temperature for annual, summer and winter seasons, spatially averaged over three regions i.e. Arabian Peninsula (AP), Northern Arabian Peninsula (NAP) and Southern Arabian Peninsula (SAP). Yellow and red bars represent the results for the near future (2030-2059) and far future (2070-2099), respectively, for

Over the Arabian Peninsula, the wet season (Oct-May) precipitation contributes the most to the annual total rainfall. The wet season precipitation shows a similar spatial distribution of future precipitation signals as compared to the annual patterns. The southern parts of the Peninsula display an increase, while the northwestern parts show a decrease in the projected precipitation (Fig. 8). The northwestern area of precipitation decrease is smaller in CMIP6 data as compared to CMIP5 data. Interestingly, the projected precipitation change during the wet season displays an identical spatial pattern, with a decrease over northwestern parts and an increase over the southern Arabian Peninsula for different scenarios. For precipitation projections, there is inconsistency among the CMIP6 models over a large part of the Arabian Peninsula. For the wet season, the agreement between CMIP6 model projections improves towards the end of the twenty-first century in both the middle (SSP2-4.5) and high emission scenarios. The signal of projected precipitation in CMIP6 models over the Arabian Peninsula is in agreement with CMIP5 model projections over the same region. The precipitation the three scenarios (SSP1-2.6, SSP2-4.5, and SSP5-8.5). The length of the bars shows Full ranges (results from all the models) and the shaded areas show Likely ranges (66\% of all projected changes are within this range)

variability is reduced in the central Peninsula for the CMIP6 ensemble, as compared to CMIP3 and CMIP5.

\subsection{Likelihood of Projected Temperature and Precipitation Signal over the Arabian Peninsula}

Projected changes in temperature over the Arabian Peninsula show a large increase in the annual and summer season, which remains a bit higher as compared to the winter (upper panels, Fig. 9). Over the AP, the annual increase of temperature is projected to be $1.56(1.63){ }^{\circ} \mathrm{C}$ with a likely range of 1.16 (1.24)-1.89 (2.1) ${ }^{\circ} \mathrm{C}$ for SSP1-2.6 in the near (far) future (Table 3). The increase will be $1.73(2.7){ }^{\circ} \mathrm{C}$ with a likely range of $1.41(2.27)-2.08$ (3.39) ${ }^{\circ} \mathrm{C}$ under SSP2-4.5, and $2.17(5.03){ }^{\circ} \mathrm{C}$ with a likely range from 1.81 (4.13) to $2.67(5.81){ }^{\circ} \mathrm{C}$ under SSP5-8.5, in the near (far) future. It is worth mentioning that while likely ranges remain similar in the high emission scenario, the full ranges of temperatures are higher in CMIP6 as compared to CMIP5. This points towards the higher sensitivity of CMIP6 climate models to the greenhouse gas (GHG) emissions. 
Table 3 CMIP6 simulated changes in mean temperature $\left({ }^{\circ} \mathrm{C}\right)$ shown as the median with likely and full ranges for the Arabian Peninsula (AP), Northern Arabian Peninsula (NAP), and Southern Arabian Peninsula (SAP) for the near (2030-2059) and far (20702099) futures with reference to the base period (1981-2010) under three different SSP scenarios

\begin{tabular}{|c|c|c|c|c|c|c|c|c|}
\hline \multirow[t]{2}{*}{ Season } & \multirow[t]{2}{*}{ Region } & \multirow[t]{2}{*}{ Scenario } & \multicolumn{3}{|c|}{ 2030-2059 } & \multicolumn{3}{|c|}{ 2070-2099 } \\
\hline & & & Median & Likely range & Full range & Median & Likely range & Full range \\
\hline \multirow[t]{9}{*}{ Annual } & \multirow[t]{3}{*}{$\mathrm{AP}$} & SSP1-2.6 & 1.56 & $1.16-1.89$ & $0.76-2.44$ & 1.63 & $1.24-2.1$ & $0.67-2.8$ \\
\hline & & SSP2-4.5 & 1.73 & $1.41-2.08$ & $1.14-2.74$ & 2.7 & $2.27-3.39$ & $1.79-4.3$ \\
\hline & & SSP5-8.5 & 2.17 & $1.81-2.67$ & $1.37-3.48$ & 5.03 & $4.13-5.81$ & $3.37-7.81$ \\
\hline & \multirow[t]{3}{*}{ NAP } & SSP1-2.6 & 1.68 & $1.26-1.96$ & $0.72-2.53$ & 1.79 & $1.32-2.19$ & $0.45-2.89$ \\
\hline & & SSP2-4.5 & 1.85 & $1.5-2.26$ & $1.1-2.88$ & 2.9 & $2.37-3.47$ & $1.78-4.46$ \\
\hline & & SSP5-8.5 & 2.3 & $2-2.79$ & $1.43-3.64$ & 5.32 & $4.42-6.06$ & $3.45-8.1$ \\
\hline & \multirow[t]{3}{*}{ SAP } & SSP1-2.6 & 1.48 & $1.07-1.77$ & $0.8-2.35$ & 1.46 & $1.1-1.99$ & $0.82-2.69$ \\
\hline & & SSP2-4.5 & 1.58 & $1.3-1.96$ & $1-2.58$ & 2.59 & $2.07-3.2$ & $1.79-4.12$ \\
\hline & & SSP5-8.5 & 2.02 & $1.55-2.42$ & $1.22-3.29$ & 4.77 & $3.91-5.63$ & $3.14-7.46$ \\
\hline \multirow[t]{9}{*}{ Summer } & \multirow[t]{3}{*}{ AP } & SSP1-2.6 & 1.64 & $1.17-2.08$ & $0.93-2.46$ & 1.78 & $1.12-2.31$ & $0.84-2.92$ \\
\hline & & SSP2-4.5 & 1.82 & $1.57-2.26$ & $1.2-2.78$ & 2.92 & $2.33-3.54$ & $1.95-4.42$ \\
\hline & & SSP5-8.5 & 2.37 & $1.85-2.78$ & $1.48-3.54$ & 5.21 & $4.14-6.14$ & $3.32-7.85$ \\
\hline & \multirow[t]{3}{*}{ NAP } & SSP1-2.6 & 1.87 & $1.27-2.35$ & $0.99-2.62$ & 1.96 & $1.4-2.57$ & $0.9-3.09$ \\
\hline & & SSP2-4.5 & 2.06 & $1.69-2.56$ & $1.36-2.97$ & 3.28 & $2.64-3.85$ & $2.11-4.72$ \\
\hline & & SSP5-8.5 & 2.72 & $2.08-3.1$ & $1.63-3.76$ & 5.87 & $5.06-6.72$ & $3.63-8.27$ \\
\hline & \multirow[t]{3}{*}{ SAP } & SSP1-2.6 & 1.39 & $0.91-1.88$ & $0.64-2.28$ & 1.51 & $0.91-2.06$ & $0.7-2.72$ \\
\hline & & SSP2-4.5 & 1.59 & $1.21-1.93$ & $0.93-2.55$ & 2.57 & $1.83-3.22$ & $1.66-4.08$ \\
\hline & & SSP5-8.5 & 1.9 & $1.41-2.42$ & $1.13-3.28$ & 4.71 & $3.28-5.61$ & $2.97-7.37$ \\
\hline \multirow[t]{9}{*}{ Winter } & \multirow[t]{3}{*}{ AP } & SSP1-2.6 & 1.43 & $1.04-1.82$ & $0.64-2.76$ & 1.35 & $1.08-1.94$ & $0.24-3.09$ \\
\hline & & SSP2-4.5 & 1.57 & $1.27-2.07$ & $0.9-2.71$ & 2.52 & $2.02-3.28$ & $1.83-4.47$ \\
\hline & & SSP5-8.5 & 1.9 & $1.51-2.62$ & $1.09-3.38$ & 4.68 & $3.77-5.73$ & $3.25-7.64$ \\
\hline & \multirow[t]{3}{*}{ NAP } & SSP1-2.6 & 1.53 & $1.14-1.91$ & $0.6-2.74$ & 1.41 & $1.12-2.04$ & $-0.04-3.13$ \\
\hline & & SSP2-4.5 & 1.54 & $1.26-2.01$ & $0.71-2.81$ & 2.5 & $2.06-3.09$ & $1.61-4.47$ \\
\hline & & SSP5-8.5 & 1.91 & $1.59-2.49$ & $0.93-3.49$ & 4.74 & $3.69-5.69$ & $3.23-7.92$ \\
\hline & \multirow[t]{3}{*}{ SAP } & SSP1-2.6 & 1.43 & $1.06-1.79$ & $0.68-2.78$ & 1.32 & $1.05-1.98$ & $0.55-3.05$ \\
\hline & & SSP2-4.5 & 1.51 & $1.24-2.13$ & $0.88-2.62$ & 2.53 & $2.06-3.22$ & $1.74-4.46$ \\
\hline & & SSP5-8.5 & 1.97 & $1.53-2.6$ & $1.11-3.33$ & 4.7 & $3.87-5.63$ & $3.05-7.35$ \\
\hline
\end{tabular}

In the summer season, the increase of temperature over the Peninsula will be $1.64(1.78){ }^{\circ} \mathrm{C}, 1.82(2.92){ }^{\circ} \mathrm{C}$, and 2.37 (5.21) ${ }^{\circ} \mathrm{C}$, under SSP1-2.6, SSP2-4.5, and SSP5-8.5, respectively, for the near (far) future. In the winter season, the increase in the projected temperature is expected to be 1.43 (1. 35) ${ }^{\circ} \mathrm{C}, 1.57(2.52){ }^{\circ} \mathrm{C}$, and 1.9 (4.68) ${ }^{\circ} \mathrm{C}$, under SSP1-2.6, SSP2-4.5, and SSP5-8.5, respectively, for the near (far) future. The projected increase in the summer temperature is larger than the projected increase in the winter temperature. The NAP is also warming faster than the SAP. For example, the increase in NAP summertime temperature is projected to be $5.87{ }^{\circ} \mathrm{C}$, but only $4.71{ }^{\circ} \mathrm{C}$ for the SAP at the end of the twenty-first century under SSP-8.5. Similarly, the increase in the annual (winter) projected temperature over NAP is 5.32 (4.74) ${ }^{\circ} \mathrm{C}$, compared with 4.77 (4.70) ${ }^{\circ} \mathrm{C}$ for SAP under SSP5-8.5. A detailed description of the likely and full ranges associated with projected temperatures over AP, NAP, and SAP is available in Table 3. Under the SSP5-8.5 scenario, NAP warming is projected to be faster than SAP warming in both summer and winter. Irrespective of the season, region, and scenario, the temperature over the Arabian Peninsula is projected to rise in the twenty-first century. Moreover, the warming over the northern Peninsula will be greater compared to the southern Peninsula in the future. These results are in agreement with the previous studies based on CMIP3 and CMIP5 datasets over Arabian Peninsula (see Almazroui et al. 2016, 2017b).

The projected precipitation also shows robust changes, either increasing or decreasing, over the Arabian Peninsula in the future period for the annual and wet season (Fig. 10). A detailed description of the precipitation changes over AP, NAP, and SAP during the wet season and annual time scale is given in Table 4. By the end of the twentyfirst century, the wet season precipitation is projected to 

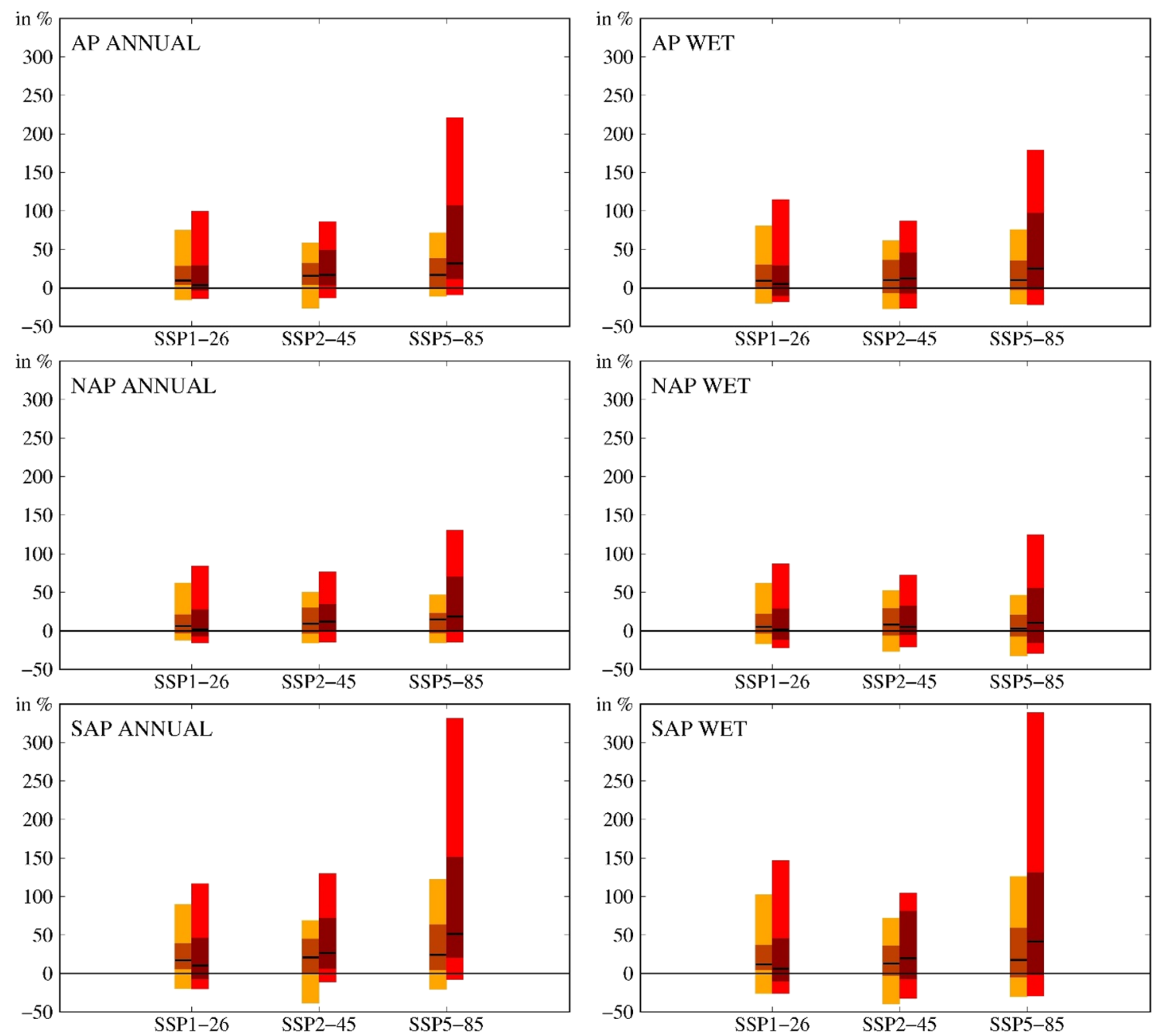

Fig. 10 Same as Fig. 9 expect showing changes in precipitaiton for the annual and wet season

increase by 5.31/12.23/25.05\% under SSP1-2.6, SSP 2-4.5, and SSP5-8.5, respectively, over the Arabian Peninsula (Table 4). For the same period and under the same scenarios, annually, the precipitation averaged over the Arabian Peninsula is likely to increase by $3.76 / 16.87 / 31.83 \%$, respectively. Moreover, the annual precipitation is projected to increase more over SAP (10-51\%) as compared to NAP (2-19\%). Precipitation projections for the wet season are similar (see Table 4). A detailed description of changes in precipitation with associated likely and full ranges under different SSP scenarios for the near and far future with reference to the base period are tabulated in Tables 4. Hence, it is clear that the southern Peninsula is likely to receive more precipitation than the northern Peninsula at the end of the twenty-first century, which is in line with findings obtained from the CMIP3 and CMIP5 datasets (Almazroui et al. 2016, 2017b).

\subsection{Trends in Projected Temperature and Precipitation Changes over the Arabian Peninsula}

The changes in temperature and precipitation under three SSP scenarios (SSP1-2.6, SSP2-4.5 and SSP5-8.5) for the entire Arabian Peninsula (AP), northern Arabian Peninsula (NAP), and southern Arabian Peninsula (SAP), for the period 2030-2099 with reference to the base period 1981-2010, are shown in Fig. 11. The median values indicate the trends, and the likely ranges (66\% around the median) represent the uncertainty ranges. The increase in temperature with reference to the base period will attain maximum value in the 2050s under the SSP1-2.6 scenario, and afterward, the increase is projected to be a bit slower for AP, NAP, and SAP. Over the AP, the rate of temperature 
Table 4 CMIP6 simulated changes in mean precipitation (in \%) shown as the median with likely and full ranges for the Arabian Peninsula (AP), Northern Arabian Peninsula (NAP), and Southern Ara- bian Peninsula (SAP) for the near (2030-2059) and far (2070-2099) futures with reference to the base period (1981-2010) under three different SSP scenarios

\begin{tabular}{|c|c|c|c|c|c|c|c|c|}
\hline \multirow[t]{2}{*}{ Season } & \multirow[t]{2}{*}{ Region } & \multirow[t]{2}{*}{ Scenario } & \multicolumn{3}{|c|}{ 2030-2059 } & \multicolumn{3}{|c|}{ 2070-2099 } \\
\hline & & & Median & Likely range & Full range & Median & Likely range & Full range \\
\hline \multirow[t]{9}{*}{ Annual } & \multirow[t]{3}{*}{$\mathrm{AP}$} & SSP1-2.6 & 9.56 & $5-27.92$ & $-15.08-74.45$ & 3.76 & $-2.56-28.8$ & $-13.29-98.97$ \\
\hline & & SSP2-4.5 & 15.54 & $4.86-31.27$ & $-25.79-57.99$ & 16.87 & $3.79-48.63$ & $-12.59-85.54$ \\
\hline & & SSP5-8.5 & 16.73 & $0.61-37.97$ & $-10.44-71.03$ & 31.83 & $11.98-106.52$ & $-8.52-220.78$ \\
\hline & \multirow[t]{3}{*}{ NAP } & SSP1-2.6 & 6.17 & $-2.49-20.86$ & $-11.6-61.55$ & 2.08 & $-6.41-26.98$ & $-15.07-83.87$ \\
\hline & & SSP2-4.5 & 9.13 & $-2.87-29.27$ & $-15.43-49.9$ & 11.87 & $0.34-34.45$ & $-14.34-75.88$ \\
\hline & & SSP5-8.5 & 14.85 & $-2.41-22.51$ & $-14.78-46.4$ & 18.89 & $-0.71-69.54$ & $-14.09-129.6$ \\
\hline & \multirow[t]{3}{*}{ SAP } & SSP1-2.6 & 17.1 & $6.39-38.46$ & $-19.1-89.31$ & 10.32 & $-6.58-45.64$ & $-19.36-116.35$ \\
\hline & & SSP2-4.5 & 20.84 & $1.58-44.47$ & $-37.72-68.49$ & 26.47 & $7.03-71.48$ & $-10.58-129.42$ \\
\hline & & SSP5-8.5 & 24.17 & $5.09-63.13$ & $-19.69-121.89$ & 51.25 & $21-150.89$ & $-7.06-330.71$ \\
\hline \multirow[t]{9}{*}{ Wet } & \multirow[t]{3}{*}{ AP } & SSP1-2.6 & 9.15 & $0.68-29.77$ & $-19.50-80.11$ & 5.31 & $-17.57-114.36$ & $-9.50-28.80$ \\
\hline & & SSP2-4.5 & 10.16 & $-5.88-35.14$ & $-26.42-61.10$ & 12.23 & $-25.79-86.50$ & $-6.77-45.26$ \\
\hline & & SSP5-8.5 & 10.01 & $-2.28-34.94$ & $-20.53-75.19$ & 25.06 & $-21.35-178.48$ & $-1.80-96.68$ \\
\hline & \multirow[t]{3}{*}{ NAP } & SSP1-2.6 & 5.25 & $-3.04-21.53$ & $-16.60-61.20$ & 1.73 & $-21.61-86.55$ & $-10.78-28.23$ \\
\hline & & SSP2-4.5 & 8.05 & $-5.28-28.61$ & $-26.12-52.11$ & 5.30 & $-20.58-72.03$ & $-4.53-32.12$ \\
\hline & & SSP5-8.5 & 2.97 & $-6.31-20.15$ & $-31.98-46.11$ & 10.28 & $-28.90-124.14$ & $-14.84-54.99$ \\
\hline & \multirow[t]{3}{*}{ SAP } & SSP1-2.6 & 11.91 & $4.90-36.04$ & $-25.36-101.88$ & 6.21 & $-25.39-146.38$ & $-9.51-45.30$ \\
\hline & & SSP2-4.5 & 13.27 & $-2.08-35.27$ & $-38.79-71.44$ & 19.93 & $-31.79-104.32$ & $-6.76-80.33$ \\
\hline & & SSP5-8.5 & 17.76 & $-4.47-58.59$ & $-29.43-125.41$ & 41.50 & $-28.81-338.246$ & $-0.77-130.80$ \\
\hline
\end{tabular}
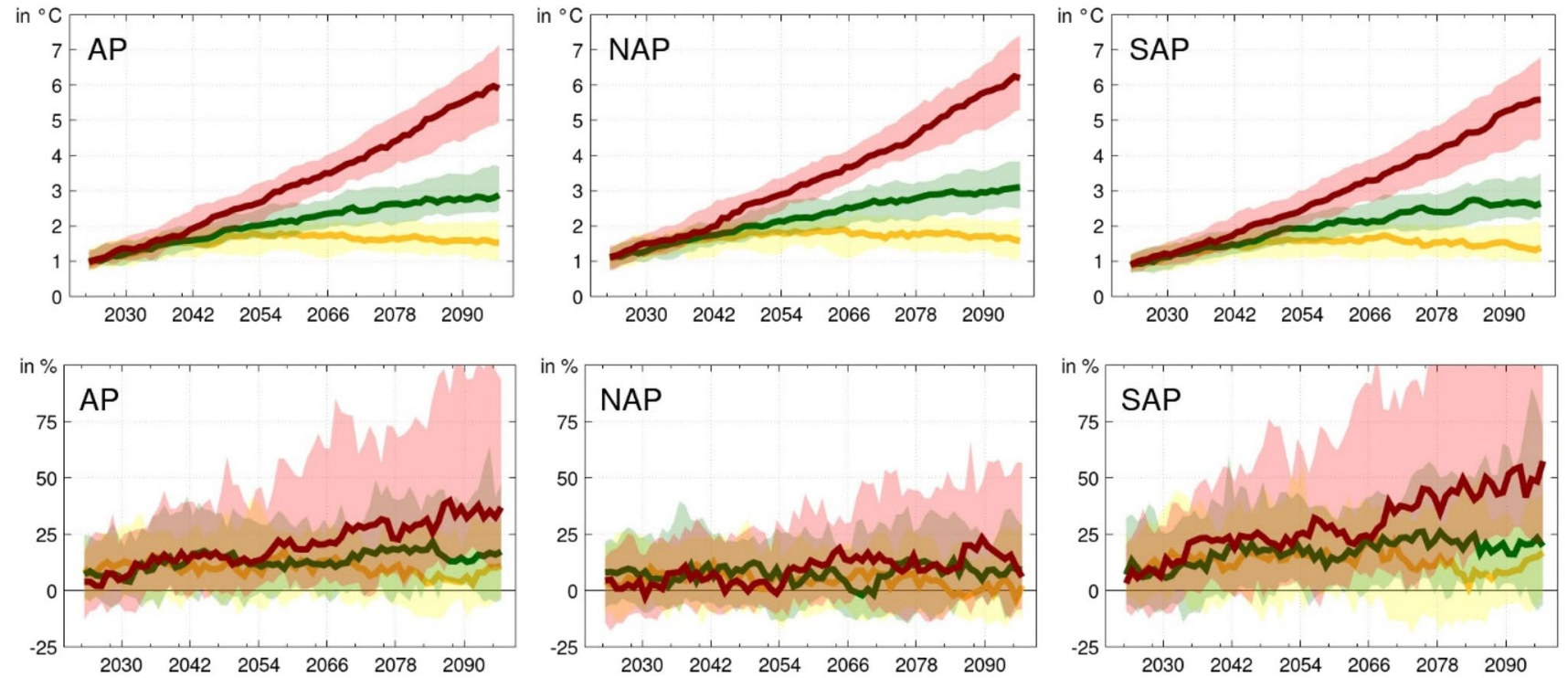

Fig. 11 The evolution of future changes in temperature (upper panels) and precipitation (lower panels) for the three regions i.e. Arabian Peninsula (AP, left column), Northern Arabian Peninsula (NAP, middle column) and Southern Arabian Peninsula (SAP, right column) during the twenty-first century. The gold, green and red curves represent the result for median values for SSP1-2.6, SSP2-4.5 and SSP5-

increase is projected to be $0.05{ }^{\circ} \mathrm{C}$ decade ${ }^{-1}$ for the entire period, which includes changes of $0.21{ }^{\circ} \mathrm{C}$ decade $^{-1}$ in the
8.5 scenarios, respectively, and the shaded areas around each curve represent the likely range (66\% of the projected changes). The curves are obtained by taking the difference of each future year with respect to the average from the control period (1981-2010) and then taking the 7-year running average

near future, and $-0.05{ }^{\circ} \mathrm{C}$ decade ${ }^{-1}$ in the far future. For the NAP (SAP), the rate of increase of temperature is projected 
to be $0.05(0.04){ }^{\circ} \mathrm{C}$ decade $^{-1}$ for the entire period, which results from $0.23(0.22){ }^{\circ} \mathrm{C}$ decade $^{-1}$ in the near future and $-0.03(-0.08){ }^{\circ} \mathrm{C}$ decade $^{-1}$ in the far future. For the SSP2-4.5 scenario, the increase in temperature is higher than that in the SSP1-2.6 scenario. Hence the increase will be at the rate of $0.26{ }^{\circ} \mathrm{C}$ decade ${ }^{-1}$ for the entire period, or $0.34{ }^{\circ} \mathrm{C} \mathrm{decade}^{-1}$ for the near future and $0.16{ }^{\circ} \mathrm{C}$ decade $^{-1}$ for the far future over the AP. The NAP shows a large increase rate $(0.29$, 0.34 , and $0.18{ }^{\circ} \mathrm{C}$ decade $^{-1}$ for the entire period, near future and far future, respectively) as compared to the SAP $(0.27$, 0.33 , and $0.17^{\circ} \mathrm{C}$ decade $^{-1}$ for the entire period, near future and far future, respectively). The SSP5-8.5 scenario shows a gradual increase in temperature, but still higher than in the other two scenarios. The increase rate is projected to be $0.70,0.58$, and $0.87^{\circ} \mathrm{C}$ decade ${ }^{-1}$ for the entire period, near future, and far future, respectively, over the AP. Over the NAP (SAP), the rise of temperature will be $0.79(0.68), 0.64$ (0.56), and $0.98(0.75){ }^{\circ} \mathrm{C}$ decade $^{-1}$ for the entire period, near future and far future, respectively. All the trends are significant at the $99 \%$ confidence level. There is a clear indication that NAP is warming at a higher rate than the SAP for the SSP5-8.5 scenario, and the increase at the end of the century will be higher compared to the previous decades. These results are in line with the CMIP3 and CMIP5 results over the Peninsula (Almazroui et al. 2016, 2017b).

The changes in precipitation for the future climate clearly indicate an increase for the SAP, which is most prominent in SSP5-8.5, while it gradually becomes less pronounced for the other two scenarios. This behavior is also reflected over the full AP. However, NAP does not show a clear trend in any of the scenarios. Over the AP, precipitation will decrease at the rate of $0.83,1.27$, and $2.18 \%$ decade $^{-1}$ under the SSP1-2.6 scenario for the entire period, near future and far future, respectively. In the case of the SSP2-4.5 (SSP5-8.5) scenario, the projected rate of change is 1.12 (4.27), 2.77 (2.93), and 0.32 (4.17) \% decade ${ }^{-1}$ for the entire period, near future, and far future, respectively. Over NAP, it is projected at $-0.73 /-0.36 / 2.16,-0.73 /-0.34 / 2.16$, and $-1.26 / 1.02 / 6.46 \%$ decade $^{-1}$ for the SSP1-2.6/SSP2-4.5/ SSP5-8.5 scenarios for the entire period, near future, and far future, respectively. Over the SAP, this rate is projected at $-1.26 / 1.02 / 6.46,0.77 / 4.25 / 6.73$, and $-4.90 /-3.96 / 8.56 \%$ decade $^{-1}$ for the SSP1-2.6/SSP2-4.5/SSP5-8.5 scenarios for the entire period, near future and far future, respectively. All the trends are significant at the 99\% confidence level, except for the SSP2-4.6 scenario over NAP and AP. It is important to note that the likely ranges are very wide for the precipitation, which implies that there is a large variation in the simulation of precipitation from model to model and the uncertainty is very high, at least from the 2050s onwards during the twenty-first century.

\section{Conclusions}

This study analyzed the multimodel ensemble from 31 CMIP6 models and examined the changes in projected temperature and precipitation over the Arabian Peninsula during the twenty-first century. We first analyzed a more updated and quality controlled observational dataset for the period 1978-2019. The observations reveal a significant increasing trend in temperature $\left(0.51{ }^{\circ} \mathrm{C}\right.$ decade $\left.^{-1}\right)$ and a decreasing trend in precipitation $\left(6.3 \mathrm{~mm} \mathrm{decade}{ }^{-1}\right)$ over the Arabian Peninsula. In the next step, the changes in projected temperature and precipitation are examined for the near future (2030-2059) and far future (2070-2099) periods, relative to the base period (1981-2010), under three SSP scenarios: SSP1-2.6, SSP2-4.5, and SSP5-8.5. Results indicate robust changes in temperature and precipitation over the Arabian Peninsula during the twenty-first century. The annual mean temperature shows a continuous increase over the Arabian Peninsula in the twenty-first century under three future scenarios. Under SPP2-4.5 (SSP5-8.5) scenarios, the temperature is projected to increase by $1.74(2.17){ }^{\circ} \mathrm{C}$ in the near future and $2.87(5.28){ }^{\circ} \mathrm{C}$ in the far future periods as compared to the base period. Moreover, the rate of increase of annual mean temperature is projected to be $0.34(0.16){ }^{\circ} \mathrm{C}$ decade $^{-1}$ over the Arabian Peninsula in the near (far) future periods under the SSP2-4.5 scenario. Under the SSP2-4.5 scenario, the NAP shows a large rate of increase $\left(0.34{ }^{\circ} \mathrm{C}\right.$ and $0.18{ }^{\circ} \mathrm{C} \mathrm{decade}{ }^{-1}$ for the near future and far future, respectively) as compared to the $\operatorname{SAP}\left(0.33{ }^{\circ} \mathrm{C}\right.$ and $0.17{ }^{\circ} \mathrm{C}$ decade $^{-1}$ for the near future and far future, respectively). The temperature is projected to rise by 0.58 and $0.87{ }^{\circ} \mathrm{C}$ decade $^{-1}$ for the near future and far future, respectively, under the SSP5-8.5 scenario over the Arabian Peninsula. Under the SSP5-8.5 scenario, the rate of increase in temperature over the NAP (SAP) is projected to be $0.64(0.98){ }^{\circ} \mathrm{C}$ and 0.56 $(0.75){ }^{\circ} \mathrm{C}$ decade $^{-1}$ for the near future and far future, respectively. These results indicate that the sensitivity of some of the CMIP6 climate models to GHG emissions is higher than the CMIP5 models.

The projected precipitation shows a robust increase (decrease) in annual mean precipitation over the southern (northern) Arabian Peninsula by the end of the twenty-first century under the three future scenarios. The projected precipitation over central parts of the Arabian Peninsula displays large variability in the future climate. Under three emission scenarios, the annual mean precipitation averaged over the Arabian Peninsula is likely to increase by $3.76-31.83 \%$ by the end of the twenty-first century. The northwestern parts of the Arabian Peninsula show a significant reduction, while southern parts of the Peninsula display a significant increase in annual mean precipitation by the end of the twenty-first century. The wet season precipitation 
is also projected to increase more over the SAP as compared to NAP under all future scenarios. The uncertainty associated with the projected precipitation increases with time; however, the projected precipitation patterns are consistent among the three SSP scenarios.

The results presented in this study are in agreement with previous publications over this region carried out with CMIP3 and CMIP5 datasets (Almazroui et al. 2016, 2017b). Overall, the CMIP6 results further enhanced our confidence in future projections of temperature and precipitation over the Arabian Peninsula for the twenty-first century. The findings of the present study will be useful for further impact studies, and ultimately for the development of adaptation strategies over the region.

Acknowledgements The authors acknowledge the World Climate Research Programme, which, through its Working Group on Coupled Modelling, coordinated and promoted CMIP6. We thank the climate modeling groups for producing and making available their model output, the Earth System Grid Federation (ESGF) for archiving the data and providing access, and the multiple funding agencies that support CMIP6 and ESGF. The CRU, GPCC, and UoD are acknowledged for providing data through their websites. The GAMEP is acknowledged for providing surface observations data. Computation for the work described in this paper was performed using Aziz Supercomputer at King Abdulaziz University's High-Performance Computing Center, Jeddah, Saudi Arabia.

\section{Compliance with ethical standards}

Conflict of interest The authors declare that they have no conflict of interest.

Open Access This article is licensed under a Creative Commons Attribution 4.0 International License, which permits use, sharing, adaptation, distribution and reproduction in any medium or format, as long as you give appropriate credit to the original author(s) and the source, provide a link to the Creative Commons licence, and indicate if changes were made. The images or other third party material in this article are included in the article's Creative Commons licence, unless indicated otherwise in a credit line to the material. If material is not included in the article's Creative Commons licence and your intended use is not permitted by statutory regulation or exceeds the permitted use, you will need to obtain permission directly from the copyright holder. To view a copy of this licence, visit http://creativecommons.org/licenses/by/4.0/.

\section{References}

Alamgir M, Ahmed K, Homsi R, Dewan A, Wang JJ, Shahid S (2019) Downscaling and projection of spatiotemporal changes in temperature of Bangladesh. Earth Syst Environ 3:381-398. https://doi.org/10.1007/s41748-019-00121-0

Almazroui M (2011) Calibration of TRMM rainfall climatology over Saudi Arabia during 1998-2009. Atmos Res 99:400-414. https:// doi.org/10.1016/j.atmosres.2010.11.006

Almazroui M (2012) Temperature variability over saudi arabia and its association with global climate indices. JKAU Met Environ Arid Land Agric Sci 23(1):85-108. https://doi.org/10.4197/Met.23-1.6
Almazroui M (2013) Simulation of present and future climate of Saudi Arabia using a regional climate model (PRECIS). Int J Climatol 33:2247-2259. https://doi.org/10.1002/joc.3721

Almazroui M (2019) Temperature changes over the CORDEX-MENA domain in the 21 st century using CMIP5 data downscaled with RegCM4: a focus on the Arabian Peninsula. Adv Meteorol. https ://doi.org/10.1155/2019/5395676 ((Article ID 5395676))

Almazroui M (2020a) Changes in temperature trends and extremes over Saudi Arabia for the period 1978-2019. Adv Meteorol 2020:8828421. https://doi.org/10.1155/2020/8828421

Almazroui M (2020b) Rainfall trends and extremes in Saudi Arabia in recent decades. Atmosphere 11:964. https://doi.org/10.3390/ atmos 11090964

Almazroui M, Saeed S (2020) Contribution of extreme daily precipitation to total rainfall over the Arabian Peninsula. Atmos Res 231:104672. https://doi.org/10.1016/j.atmosres.2019.104672

Almazroui M, Islam MN, Athar H, Jones PD, Rahman MA (2012) Recent climate change in the Arabian Peninsula: annual rainfall and temperature analysis of Saudi Arabia for 1978-2009. Int J Climatol 32:953-966. https://doi.org/10.1002/joc.3446

Almazroui M, Islam MN, Jones PD (2013) Urbanization effects on the air temperature rise in Saudi Arabia. Clim Chang 120(1-2):109122. https://doi.org/10.1007/s10584-013-0796-2

Almazroui M, Abid MA, Athar H, Islam MN, Ehsan MA (2013) Interannual variability of rainfall over the Arabian Peninsula using the IPCC AR4 Global Climate Models. Int J Climatol 33:2328-2340. https://doi.org/10.1002/joc.3600

Almazroui M, Islam MN, Dambul R, Jones PD (2014) Trends of temperature extremes in Saudi Arabia. Int J Climatol 34:808-826. https://doi.org/10.1002/joc.3722

Almazroui M, Saeed F, Islam MN, Alkhalaf AK (2016) Assessing the robustness and uncertainties of projected changes in temperature and precipitation in AR4 Global Climate Models over the Arabian Peninsula. Atmos Res 182:163-175. https://doi.org/10.1016/j. atmosres.2016.07.025

Almazroui M, Islam MN, Sajjad S, Alkhalaf AK, Ramzah D (2017a) Assessment of uncertainties in projected temperature and precipitation over the Arabian peninsula using three categories of Cmip5 multimodel ensembles. Earth Syst Environ 1:23. https:// doi.org/10.1007/s41748-017-0027-5

Almazroui M, Islam MN, Fahad S, Alkhalaf AK, Dambul R (2017b) Assessing the robustness and uncertainties of projected changes in temperature and precipitation in AR5 Global Climate Models over the Arabian Peninsula. Atmos Res 194:202-213. https://doi. org/10.1016/j.atmosres.2017.05.005

Almazroui M, Saeed S, Islam MN, Khalid MS, Alkhalaf AK, Dambul R (2017c) Assessment of uncertainties in projected temperature and precipitation over the Arabian Peninsula: a comparison between different categories of CMIP3 models. Earth Syst Environ 1:12. https://doi.org/10.1007/s41748-017-0012-z

AlSarmi SH, Washington R (2013) Changes in climate extremes in the Arabian Peninsula: analysis of daily data. Int J Climatol 34:1329_ 1345. https://doi.org/10.1002/joc.3772

Attada R, Dasari HP, Chowdary JS, Yadav RK, Knio O, Hoteit I (2018a) Surface air temperature variability over the Arabian Peninsula and its links to circulation patterns. Int J Climatol 39:445464. https://doi.org/10.1002/joc.5821

Attada R, Yadav RK, Kunchala RK, Dasari HP, Knio O, Hoteit (2018b) Prominent mode of summer surface air temperature variability and associated circulation anomalies over the Arabian Peninsula. Atmos Sci Lett. https://doi.org/10.1002/asl.860

Barfus K, Bernhofer C (2014) Assessment of GCM performances for the Arabian Peninsula, Brazil, and Ukraine and indications of regional climate change. Environ Earth Sci 72:4689-4703. https ://doi.org/10.1007/s12665-014-3147-3 
Bi D, Dix M, Marsland S et al (2012) The ACCESS coupled model: description, control climate and evaluation. Aust Meteorol Oceanogr J 63:41-64. https://doi.org/10.22499/2.6301.004

Bucchignani E, Mercogliano P, Panitz HJ, Montesarchio M (2018) Climate change projections for the Middle EasteNorth Africa domainwith COSMO-CLM at different spatial resolutions. Adv Clim Change Res 9(1):66-80. https://doi.org/10.1016/j.accre .2018.01.004

Cao J, Wang B, Yang YM, Ma L, Li J, Sun B, Bao Y, He J, Zhou X, Wu L (2018) The NUIST Earth System Model (NESM) version 3: description and preliminary evaluation. Geosci Model Dev 11:2975-2993. https://doi.org/10.5194/gmd-11-2975-2018

Ehsan MA, Nicolì D, Kucharski F, Almazroui M et al (2020) Atlantic Ocean influence on Middle East summer surface air temperature. NPJ Clim Atmos Sci. https://doi.org/10.1038/s41612-020-0109-1 ((Article No. 5))

Eyring V, Bony S, Meehl GA, Senior CA, Stevens B, Stouffer RJ, Taylor KE (2016) Overview of the Coupled Model Intercomparison Project Phase 6 (CMIP6) experimental design and organization. Geosci Model Dev 9:1937-1958. https://doi.org/10.5194/ gmd-9-1937-2016

Folland CK, Rayner NA, Brown SJ, Smith TM, Shen SSP, Parker DE, Macadam I, Jones PD, Jones RN, Nicholls N, Sexton DMH (2001) Global temperature change and its uncertainties since 1861 . Geophys Res Lett 28:2621-2624. https://doi.org/10.1029/2001G L012877

Gutjahr O, Putrasahan D, Lohmann K, Jungclaus JH, von Storch JS, Brüggemann N, Haak H, Stössel A (2019) Max planck institute earth system model (MPI-ESM1.2) for the high-resolution model intercomparison project (HighResMIP). Geosci Model Dev 12:3241-3281. https://doi.org/10.5194/gmd-12-3241-2019

Haarsma RJ, Roberts MJ, Vidale PL et al (2016) High Resolution Model Intercomparison Project (HighResMIP v1.0) for CMIP6. Geosci Model Dev 9:4185-4208. https://doi.org/10.5194/ gmd-9-4185-2016

Haensler A, Saeed F, Jacob D (2013) Assessing the robustness of projected precipitation changes over central Africa on the basis of a multitude of global and regional climate projections. Clim Chang 121(2):349-363. https://doi.org/10.1007/s1058 4-013-0863-8

Hajima T, Watanabe M, Yamamoto A, Tatebe H, Noguchi MA, Abe M, Ohgaito R, Ito A, Yamazaki D, Okajima H, Ito A, Takata K, Ogochi K, Watanabe S, Kawamiya M (2019) Description of the MIROC-ES2L Earth system model and evaluation of its climatebiogeochemical processes and feedbacks. Geosci Model Dev Discuss. https://doi.org/10.5194/gmd-2019-275, inreview

Harris IC, Jones PD (2015) CRU TS3.23: climatic research unit (CRU) time-series (TS) version 3.23 of high resolution gridded data of month-by-month variation in climate (Jan. 1901-Dec. 2014). Centre Environ Data Anal. https://doi.org/10.5285/4c7fdfa6-f176$4 c 58$-acee-683d5e9d2ed5

Hasanean H, Almazroui M (2015) Review rainfall: features and variations over Saudi Arabia. A Rev Clim 3(3):578-626. https://doi. org/10.3390/cli3030578

He B et al (2019) CAS FGOALS-f3-L model datasets for CMIP6 historical Atmospheric Model Inter-comparison Project simulation. Adv Atmos Sci 36(8):771-778. https://doi.org/10.1007/ s00376-019-9027-8

Held IM, Guo H, Adcroft A, Dunne JP, Horowitz LW, Krasting J et al (2019) Structure and performance of GFDL's CM4.0 climate model. J Adv Model Earth Syst. https://doi.org/10.1029/2019M S001829

IPCC (2013) Climate Change 2013: The Physical Science Basis, Contributionof Working Group I to the Fifth Assessment Report of the Intergovernmental Panel on Climate Change. Cambridge University Press, Cambridge and New YorkKotwicki V, Al Sulaimani Z
(2009) Climates of the Arabian Peninsula - past, present, future. Int J Clim Chan Strat Managem 1(3):297-310

Islam MN, Almazroui M, Dambul R, Jones PD, Alamoudi AO (2015) Long-term changes in seasonal temperature extremesoverSaudiArabiaduring 1981-2010. Int J Climatol 35(7):1579-1592. https ://doi.org/10.1002/joc.4078

Kothawale DR, Munot AA, Krishna KK (2010) Surface air temperature variability over India during 1901-2007, and its association with ENSO. Clim Res 42:89-104. https://doi.org/10.3354/cr00857

Kotwicki V, Al Sulaimani Z (2009) Climates of the Arabian Peninsula - past, present, future. Int J Clim Change Strategies Manag 1(3):297-310. https://doi.org/10.1108/17568690910977500

Lauritzen PH, Nair RD, Herrington AR, Callaghan P, Goldhaber S, Dennis JM et al (2018) NCAR release of CAM-SE in CESM2.0: a reformulation of the spectral element dynamical core in dry-mass vertical coordinates with comprehensive treatment of condensates and energy. J Advan Model Earth Syst 10:1537-1570. https://doi. org/10.1029/2017MS001257

Law RM, Ziehn T, Matear RJ, Lenton A et al (2017) The carbon cycle in the Australian Community Climate and Earth System Simulator (ACCESS-ESM1) - Part 1: Model description and pre-industrial simulation. Geosci Model Dev 10:2567-2590. https://doi. org/10.5194/gmd-10-2567-2017

Lin Y, Huang X, Liang Y et al (2020) Community Integrated Earth System Model (CIESM): Description and Evaluation. J Adv Model Earth Syst. https://doi.org/10.1029/2019MS002036

Liu SM, Chen YH, Rao J, Cao C, Li SY, Ma MH, Wang YB (2019) Parallel comparison of major sudden stratospheric warming events in CESM1-WACCM and CESM2-WACCM. Atmosphere 10:679

Massonnet F, Ménégoz M, Acosta M et al (2020) Replicability of the EC-Earth3 Earth system model under a change in computing environment. Geosci Model Dev 13:1165-1178. https://doi. org/10.5194/gmd-13-1165-2020

O'Neill BC, Tebaldi C, van Vuuren DP, Eyring V, Friedlingstein P, Hurtt G, Knutti R, Kriegler E, Lamarque J-F, Lowe J, Meehl GA, Moss R, Riahi K, Sanderson BM (2016) The Scenario Model intercomparison project (ScenarioMIP) for CMIP6. Geosci Model Dev 9:3461-3482. https://doi.org/10.5194/gmd-9-3461-2016

Pal J, Eltahir E (2016) Future temperature in southwest Asia projected to exceed a threshold for human adaptability. Nat Clim Chang 6:197-200. https://doi.org/10.1038/nclimate2833

Rashid IU, Almazroui M, Saeed S, Atif RM (2020) Analysis of extreme summer temperatures in Saudi Arabia and the association with large-scale atmospheric circulation. Atmos Res 231:104659. https ://doi.org/10.1016/j.atmosres.2019.104659

Riahi K, Vuuren V et al (2017) The shared socioeconomic pathways and their energy, land use, and greenhouse gas emissions implications: an overview. Global Environ Change 42:153-168

Rong XY, Li J, Chen HM et al (2019) Introduction of CAMSCSM model and its participation in CMIP6 [J]. Clim Chang Res 15(5):540-544. https://doi.org/10.12006/j.i ssn.1673-1719.2019.186

Schneider U, Becker A, Finger P, Meyer-Christoffer A, Rudolf B, Ziese M (2016) GPCC Full Data Reanalysis Version 7.0: Monthly Land-Surface Precipitation from Rain Gauges built on GTS based and Historic Data. Research Data Archive at the National Center for Atmospheric Research, Computational and Information Systems Laboratory. https://doi.org/10.5065/D6000072

Séférian R, Nabat P, Michou M, Saint-Martin D, Voldoire A, Colin JA (2019) Evaluation of CNRM Earth-System model, CNRMESM2-1: role of Earth system processes in present-day and future climate. J Adv Model Earth Syst. https://doi.org/10.1029/2019M S001791

Sellar A, Jones C, Mulcahy J, Tang Y et al (2019) UKESM1: description and evaluation of the UK Earth System Model. J Advan Model Earth Syst. https://doi.org/10.1029/2019MS001739 
Solomon S, Qin D, Manning M, Chen Z, Marquis M, Averyt K, Tignor M, Miller H (eds) (2007) Contribution of Working Group I to the Fourth Assessment Report of the Intergovernmental Panel on Climate Change. Cambridge University Press, Cambridge

Song Y, Li X, Bao Y et al (2020) FIO-ESM v2.0 Outputs for the CMIP6 Global Monsoons Model Intercomparison Project Experiments. Adv Atmos Sci 37:1045-1056

Swart NC, Cole JNS, Kharin VV, Lazare M, Scinocca JF, Gillett NP, Anstey J, Arora V, Christian JR, Hanna S, Jiao Y, Lee WG, Majaess F, Saenko OA, Seiler C, Seinen C, Shao A, Sigmond M, Solheim L, von Salzen K, Yang D, Winter B (2019) The Canadian Earth System Model version 5 (CanESM5.0.3). Geosci Model Dev 12:4823-4873. https://doi.org/10.5194/gmd-12-4823-2019

Syed FS, Latif M, Al-Maashi A, Ghulam A (2019) Regional climate model RCA4 simulations of temperature and precipitation over the Arabian Peninsula: sensitivity to CORDEX domain and lateral boundary conditions. Clim Dyn 53:7045-7064. https://doi. org/10.1007/s00382-019-04974-z

Tatebe H, Ogura T, Nitta T, Komuro Y, Ogochi K, Takemura T, Sudo K, Sekiguchi M, Abe M, Saito F, Chikira M, Watanabe S, Mori M, Hirota N, Kawatani Y, Mochizuki T, Yoshimura K, Takata K, O'ishi R, Yamazaki D, Suzuki T, Kurogi M, Kataoka T, Watanabe M, Kimoto M (2019) Description and basic evaluation of simulated mean state, internal variability, and climate sensitivity in MIROC6. Geosci Model Dev 12:2727-2765. https://doi. org/10.5194/gmd-12-2727-2019
Volodin EM, Mortikov EV, Kostrykin SV et al (2018) Simulation of the modern climate using the INM-CM48 climate model. Russian J Num Analy Math Model 33(6):367-374. https://doi.org/10.1515/ rnam-2018-0032

Voldoire A, Saint-Martin D, Sénési S, Decharme B, Alias A, Chevallier M et al (2019) Evaluation of CMIP6 DECK experiments with CNRM-CM6-1. J Advan Model Earth Syst 11:2177-2213. https ://doi.org/10.1029/2019MS001683

Willmott CJ, Matsuura K (2001) Terrestrial Air Temperature and Precipitation: Monthly and Annual Time Series (1950-1999). Available at https://climate.geog.udel.edu/ climate/html_pages/ README.ghcn_ts $2 . h t m l$

Wu T, Lu Y, Fang Y, Xin X, Li L, Li W, Jie W, Zhang J, Liu Y, Zhang L, Zhang F, Zhang Y, Wu F, Li J, Chu M, Wang Z, Shi X, Liu X, Wei M, Huang A, Zhang Y, Liu X (2019) The Beijing Climate Center Climate System Model (BCC-CSM): the main progress from CMIP5 to CMIP6. Geosci Model Dev 12:1573-1600. https ://doi.org/10.5194/gmd-12-1573-2019

Yukimoto S, Kawai H, KoshiroT ON, Yoshida K, Urakawa S, Tsujino H, Deushi M, Tanaka T, Hosaka M, Yabu S, Yoshimura H, Shindo E, Mizuta R, Obata A, Adachi Y, Ishii M (2019) The Meteorological Research Institute Earth System Model version 2.0, MRIESM2.0: description and basic evaluation of the physical component. J Meteor Soc Japan 97:000-000. https://doi.org/10.2151/ jmsj.2019-051 